\title{
O gênero Mimosa L. (Leguminosae: Mimosoideae) na APA Serra Branca/Raso da Catarina, Bahia, Brasil
}

\author{
Diego Augusto Oliveira Dourado ${ }^{1}$, Adilva de Souza Conceição ${ }^{1,3}$ \& Juliana Santos-Silva ${ }^{2}$ \\ ${ }^{1}$ Programa de Pós-graduação em Biodiversidade Vegetal, Departamento de Educação, \\ Universidade do Estado da Bahia - UNEB, Campus VIII, Rua do Gangorra, 503, Bairro Alves de Souza, \\ CEP 48608-240, Paulo Afonso, BA, Brasil. http://www.uneb.br/ \\ ${ }^{2}$ Departamento de Ciências Humanas, Universidade do Estado da Bahia - UNEB, Campus VI, \\ Av. Contorno, s/n., São José, CEP 46400-000, Caetité, BA, Brasil. http://www.uneb.br/ \\ ${ }^{3}$ Autor para correspondência: Adilva de Souza Conceição, e-mail: adilva.souza@gmail.com
}

DOURADO, D.A.O., CONCEIÇÃO, A.S. \& SANTOS-SILVA, J. The genus Mimosa L. (Leguminosae: Mimosoideae) in the Serra Branca APA/Raso da Catarina, Bahia, Brazil. Biota Neotrop. 13(4):http://www. biotaneotropica.org.br/v13n4/en/abstract?inventory+bn01713042013

\begin{abstract}
This work consists of a floristic survey of the genus Mimosa L. in APA Serra Branca/Raso da Catarina, located in Jeremoabo, Bahia, Brazil. We analyzed specimens collected from June/2010 to October/2011 and collections deposited in the ALCB, HRB, HUEFS, and MBM herbaria. We registered 11 species distributed in two sections: Mimosa sect. Batocaulon DC. (Mimosa acutistipula (Mart.) Benth. var.acutistipula, M. adenophylla var. mitis Barneby, M. arenosa (Willd.) Poir. var. arenosa, M. caesalpiniifolia Benth., M. lewisii Barneby, M. misera Benth., M. piscatorum Barneby, M. quadrivalvis var. leptocarpa (DC.) Barneby, and M. tenuiflora (Willd.) Poir.) and Mimosa sect. Mimosa (M. pudica var. tetrandra (Humb. \& Bonpl. ex Willd.) DC. And M. sensitive L. var. sensitiva). The main characters used for delimitation of the species were inflorescence morphology, number of pinnae, leaflets, perianth elements and stamens, as well as aspects from the fruit. The species occurs mainly open areas and more degraded along trails on sandy soils. Keys for identification of species, descriptions, illustrations and comments about geographic distribution and flowering and fruiting periods of the species are presented. Keywords: caatinga, diversity, floristic, Jeremoabo, semiarid.
\end{abstract}

DOURADO, D.A.O., CONCEIÇÃO, A.S. \& SANTOS-SILVA, J. O gênero Mimosa L. (Leguminosae: Mimosoideae) na APA Serra Branca/Raso da Catarina, Bahia, Brasil. Biota Neotrop.13(4): http://www. biotaneotropica.org.br/v13n4/pt/abstract?inventory+bn01713042013

Resumo: Este trabalho consiste no levantamento florístico do gênero Mimosa L. na APA Serra Branca/Raso da Catarina, localizada no município de Jeremoabo, Bahia. Foram analisados espécimes coletados no período de junho/2010 a outubro/2011 e coleções herborizadas depositadas nos Herbários ALCB, HRB, HUEFS e MBM. Foram registradas 11 espécies, distribuídas em duas seções: Mimosa sect. Batocaulon DC. (Mimosa acutistipula (Mart.) Benth. var. acutistipula, M. adenophylla var. mitis Barneby, M. arenosa (Willd.) Poir. var.arenosa, M. caesalpiniifolia Benth., M. lewisii Barneby, M. misera Benth., M. piscatorum Barneby, M. quadrivalvis var. leptocarpa (DC.) Barneby e M. tenuiflora (Willd.) Poir.) e Mimosa sect. Mimosa (M. pudica var. tetrandra (Humb. \& Bonpl. ex Willd.) DC. e M. sensitiva L. var. sensitiva). Os principais caracteres morfológicos utilizados para separação das espécies foram os tipos de inflorescências, número de pinas, folíolos, de elementos do perianto e de estames, além do aspecto do fruto. As espécies ocorrem principalmente em áreas abertas e mais degradadas ao longo de trilhas, sobre solos arenosos. São apresentadas chaves para identificação das espécies, descrições, ilustrações, comentários sobre distribuição geográfica e períodos de floração e frutificação das espécies.

Palavras-chave: caatinga, diversidade, florística, Jeremoabo, semiárido. 


\section{Introdução}

Mimosa L. com mais de 540 espécies, é o segundo maior gênero de Mimosoideae, (Simon et al. 2011). Distribui-se predominantemente na região Neotropical, com cerca de 496 táxons endêmicos dos Neotrópicos e 40 espécies são nativas do Velho Mundo (Barneby 1991, Simon et al. 2011). Suas espécies podem ser encontradas em diferentes ambientes, desde florestas até áreas mais abertas de savanas, campos, caatingas, ou ainda, em regiões desérticas do México (Barneby 1991). Os seus principais centros de diversidade localizam-se na América do Sul (Brasil, Paraguai, Uruguai e Argentina) e no Centro-sul do México (Barneby 1985, 1991, Lewis et al. 2005). No Brasil está representado por cerca de 323 espécies (Dutra \& Morim 2010), das quais 38 ocorrem na caatinga (Queiroz 2009).

O gênero Mimosa foi estabelecido por Linnaeus (1753) com 53 espécies. Tratamentos taxonômicos mais abrangentes foram realizados por Bentham (1841, 1875, 1876), Burkart (1948) e Barneby (1985). Em 1991, Barneby realizou a revisão mais completa do gênero, incluindo 479 espécies do Novo Mundo. Neste trabalho foram descritas cerca de 130 espécies novas e estabelecidos 200 táxons infraespecíficos. Baseado principalmente na presença ou ausência de nectários extraflorais na raque foliar, nos tipos de tricomas e nas características florais, Barneby (1991) reconheceu cinco seções para o gênero: Mimosa sect. Mimadenia Barneby, Mimosa sect. Batocaulon DC., Mimosa sect. Calothamnos Barneby, Mimosa sect. Habbasia DC. e Mimosa sect. Mimosa.

Estudos filogenéticos demonstram que o gênero Mimosa, como tradicionalmente circunscrito, constitui um grupo monofilético (Luckow et al. 2000, 2003, Sulaiman et al. 2003, Jobson \& Luckow 2007, Bessega et al. 2008, Simon et al. 2011). No entanto, com relação a sua classificação infragenérica, apenas as seções $M$. sect. Mimadenia e $M$. sect. Calothamnos, se sustentaram como grupos monofiléticos (Coutinho 2009, Simon et al. 2011).

O gênero Mimosa é caracterizado principalmente pelo fruto do tipo craspédio (mais raramente lomento ou sacelo), apresentando margens persistentes (replo), com valvas inteiras ou mais frequentemente segmentadas em artículos monospérmicos. Além disso, as flores são isostêmones ou diplostêmones e as anteras não apresentam glândulas apicais, o que diferencia Mimosa de gêneros afins como Anadenanthera Speg., Parapiptadenia Brenan, Plathymenia Benth., Piptadenia Benth., Prosopis L. e Pseudopiptadenia Rauschert (Queiroz 2009).

As espécies de Mimosa foram tratadas em várias floras regionais. Considerando os levantamentos florísticos realizados na região Nordeste, podemos destacar os trabalhos de Ducke (1953), na Paraíba e Pernambuco; Harley \& Simmons (1986), em Mucugê (Bahia); Lewis (1987), na Bahia; Lewis (1995), Pico das Almas (Bahia); Lewis (2006), checklist Nordeste; Queiroz (2009), na Caatinga e Santos-Silva \& Sales (2008, 2010), em Pernambuco. Pelo exposto, embora a quantidade de trabalhos incluindo as espécies de Mimosa ocorrentes no Nordeste seja razoável, os trabalhos específicos sobre o gênero são escassos, especialmente os que incluem chaves de identificação e descrições.

A caatinga ocupa uma área de $1.037 .517 \mathrm{~km}^{2}$ no semiárido brasileiro, abrangendo nove estados nordestinos, além da região norte do estado de Minas Gerais (Alves 2007). É composta por uma vegetação xerófita, caducifólia, espinhosa com plantas suculentas ou áfilas (Andrade-Lima 1981, Fernandes \& Bezerra 1998). A caatinga é uma formação vegetacional exclusivamente brasileira, reconhecida como uma das 37 grandes áreas naturais do planeta (Gil 2002). Abriga uma grande diversidade de espécies tanto da fauna como da flora, sendo em sua grande parte endêmicas (Castelletti et al. 2004,
Leal et al. 2003). Giulietti et al. (2002) listaram para o ecossistema, 18 gêneros e 318 espécies endêmicas, pertencentes a 42 famílias. A família com maior número de espécies endêmicas (ca. 80) é a Leguminosae, que é também o grupo mais bem representado nas caatingas (Queiroz 2002). Dentre os gêneros característicos deste bioma encontram-se: Cereus Mill., Jatropha L., Mimosa L., Spondias L., entre outros (Sampaio 1995). Com alto grau de endemismo, a caatinga é ainda um dos ecossistemas brasileiros mais desvalorizado e mal conhecido botanicamente (Giulietti et al. 2004). Além disso, é o segundo ecossistema mais degradado do Brasil (Leal et al. 2005).

O Raso da Catarina, uma das oito ecorregiões da caatinga, situase no Nordeste do Brasil e limita-se com a Depressão Sertaneja Meridional (norte, oeste e leste), Planalto da Borborema (nordeste) e com o Recôncavo Baiano (sul). A Área de Proteção Ambiental (APA) Serra Branca é uma das Unidades de Conservação (UC) existentes na ecorregião do Raso da Catarina. Esta APA foi criada através do decreto estadual $n^{\circ} 7972$ de 05 de junho de 2001, com objetivo de preservar a vegetação da caatinga; assegurar a diversidade genética da fauna e seus processos evolutivos (em especial a avifauna migratória) e possibilitar a formação de um corredor ecológico com a Estação Ecológica do Raso da Catarina (Instituto... 2004).

Diante da expressiva importância do gênero Mimosa na vegetação de caatinga, este estudo teve por objetivo conhecer a diversidade do gênero na APA Serra Branca, visando contribuir para o conhecimento da flora do estado da Bahia, bem como fornecer subsídios para o desenvolvimento do plano de manejo desta unidade de conservação.

\section{Material e Métodos}

Área de estudo - A APA Serra Branca/Raso da Catarina (Figura 1), com 67.237 ha. está localizada no município de Jeremoabo, nordeste da Bahia, delimitada pelas coordenadas $09^{\circ} 53^{\prime} 15,5^{\prime \prime}$ a 0944'34,6"S e $38^{\circ} 49^{\prime} 36,1^{\prime \prime}$ 'a $38^{\circ} 52$ '20,4”'W, limitando-se ao sul com o rio Vaza-Barris e ao norte com a Estação Ecológica (ESEC) Raso da Catarina. O clima da região é semiárido, com precipitação média de $600 \mathrm{~mm} /$ ano e temperatura média anual de $27^{\circ} \mathrm{C}$. Os solos são em geral arenosos, profundos, extremamente ácidos e pobres em nutrientes. A vegetação predominante é a caatinga arbustiva (Velloso et al. 2002).

Estudo taxonômico - De junho/2010 a outubro/2011 foram realizadas coletas nas diferentes áreas da APA Serra Branca, de acordo com a metodologia de Fosberg \& Sachet (1965) e Mori et al. (1989). Após processamento, o material coletado foi depositado no acervo do herbário da Universidade do Estado da Bahia (HUNEB - Coleção Paulo Afonso), com duplicatas enviadas para os principais herbários do Estado. Foram examinadas ainda exsicatas provenientes dos herbários: ALCB, HRB, HUEFS, MBM (Thiers 2011; Apêndice 1). A identificação dos espécimes foi baseada principalmente em Barneby (1991), protólogos e em imagens de coleções-tipo. A padronização da terminologia das estruturas vegetativas e reprodutivas baseou-se Radford et al. (1974), Barneby (1991) e Harris \& Harris (1994). As informações sobre distribuição geográfica, ambiente preferencial, períodos de floração e frutificação das espécies foram obtidos nas etiquetas das exsicatas, observações de campo e referenciadas quando complementadas com informações da literatura.

\section{Resultados e Discussão}

Mimosa L., Sp. P1. 1: 516.1753. Espécie-tipo: Mimosa sensitiva L.

Árvores, arbustos, subarbustos, trepadeiras, ou ervas, prostrados, decumbentes ou eretos. Ramos cilíndricos ou 4-angulosos, inermes ou aculeados; acúleos retos ou recurvados. Indumento formado por tricomas tectores, glandulares ou ramificados. Folhas 


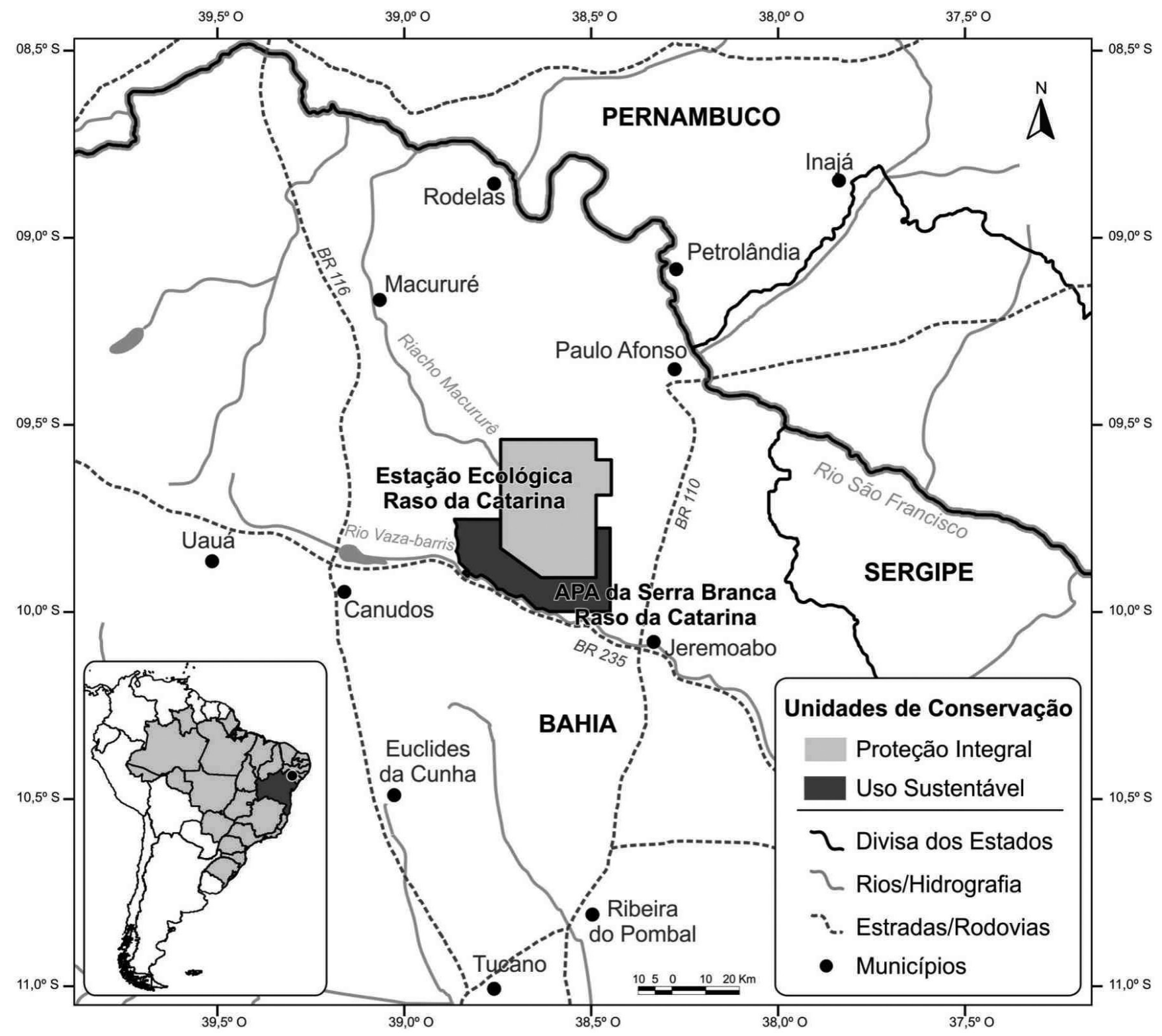

Figura 1. Localização da APA Serra Branca/Raso da Catarina.

Figure 1. Location of the APA Serra Branca/Raso da Catarina.

bipinadas, 1-multipinas; estípulas persistentes ou decíduas, às vezes, espinescentes; espículas presentes ou ausentes entre os pares de pinas, parafilídios presentes ou ausentes nas pinas, nectário extrafloral comumente ausente. Inflorescências em glomérulos ou em espigas, solitárias ou 2-3-fasciculadas, axilares ou reunidas em pseudoracemos ou panículas terminais. Flores sésseis ou curtamente pediceladas, 3-5-(-6)-meras, isostêmones ou diplostêmones; cálice campanulado tubuloso ou papiforme; corola campanulada, tubulosa, 4-angulada ou campanulada, lacínias patentes, reflexas ou eretas; filetes brancos róseos ou lilás; anteras oblongas ou ovoides; estilete filiforme, branco ou róseo; estigma inconspícuo; ovário séssil ou subséssil. Fruto craspédio, lomento ou sacelo, séssil ou estipitado, plano-compresso ou quadrangular em seção transversal; replo reto, ondulado ou discretamente sinuoso, armado ou inerme. Sementes elipsoides, oblongoides ou ovoides, marrons, castanhas ou acinzentadas.

$\mathrm{Na}$ APA Serra Branca/Raso da Catarina foram registrados 11 táxons de Mimosa, o que representa $18 \%$ das espécies do gênero ocorrentes na Bahia. Destes, sete táxons são exclusivos da América do Sul, sendo quatro restritos ao Brasil. Os demais distribui-se desde a porção sul da América do Norte (México), passando pela América Central até a América do Sul. De maneira geral, estas plantas habitam principalmente tipos vegetacionais mais secos como cerrado, caatinga e floresta estacional. Na área de estudo, a maioria das espécies ocorre em áreas degradadas, antropizadas, ao longo das trilhas, sobre solos arenosos ou areno-argilosos.

As espécies aqui tratadas são distribuídas em duas seções: Mimosa sect. Batocaulon (Mimosa acutistipula (Mart.) Benth. var. acutistipula, M. adenophylla var. mitis Barneby, M. arenosa (Willd.) Poir. var. arenosa, M. caesalpiniifolia Benth., M. lewisii Barneby, M. misera Benth., M. piscatorum Barneby, M. quadrivalvis var. leptocarpa (DC.) Barneby e M. tenuiflora (Willd.) Poir.) e Mimosa sect. Mimosa (M. pudica var. tetrandra (Humb. \& Bonpl. ex Willd.) DC. e M. sensitiva L. var. sensitiva). Os caracteres morfológicos mais relevantes para o reconhecimento das espécies foram observados no 
número de pinas, folíolos, elementos do perianto e estames, tipo de inflorescência, além do aspecto dos frutos.

Mimosa é um grupo funcionalmente importante dentro do ecossistema terrestre (Santos-Silva \& Sales 2010). Várias de suas espécies são pioneiras, colonizando locais perturbados, tais como beira de estradas, margem de rios e clareiras de matas. Essa característica se deve principalmente ao seu rápido crescimento e à sua capacidade de regeneração vegetativa (Camargo-Ricalde \& Grether 1998). Nessas áreas promovem o enriquecimento do solo e evitam a sua erosão e, portanto facilitam o estabelecimento de outras plantas (Camargo-Ricalde \& García-García 2001), o que torna suas espécies boas candidatas para a restauração de áreas degradadas.

Chave para identificação das espécies de Mimosa na APA Serra Branca

1. Folíolos com pontuações glandulares na face abaxial.

2. Ramos aculeados; estípulas $0,8-1 \times$ ca. $0,5 \mathrm{~mm}$, triangulares; pecíolo 0,6-1,4 cm compr.; filetes 3-4 mm compr., brancos; ovário séssil, puberulento 11. M. tenuiflora

2'. Ramos inermes; estípulas 2-4 × ca. 0,8 mm, subulada-lanceoladas; pecíolo 1-2 cm compr.; filetes 6-7 mm compr., róseos; ovário subséssil, piloso. 2. M. adenophylla var. mitis

1'. Folíolos sem pontuações glandulares na face abaxial.

3. Arvoretas a arbustos 1-6 m altura; filetes brancos.

4. Folíolos oval-obovais, 2-4 pares; flores trímeras 4. M. caesalpiniifolia

4'. Folíolos lineares ou oblongos, 10-54 pares; flores tetrâmeras.

5. Folíolos cartáceos; parafilídios cilíndricos; flores reunidas em glomérulos. 5. M. lewisii

5. Folíolos membranáceos; parafilídios cônicos; flores reunidas em espigas.

6. Folhas com 6-10 pares de pinas; nervação acródroma; corola branca; craspédios $(2-) 3-5 \times 0,5-0,7 \mathrm{~cm}$.

3. M. arenosa var. arenosa

6'. Folhas com (3-)4-5 pares de pinas; nervação camptódroma; corola branco-rosada; craspédios 5-7,5 × 0,8-1 cm

1. M. acutistipula var. acutistipula

3'. Subarbustos de 0,2-2 m altura; filetes róseos.

7. Nervação broquidódroma.

8. Acúleos retos, infranodais, distribuídos aos pares; folíolos 5-9 $\times$ 1-2 mm, linear-oblongos; inflorescência com 108-128 flore ............ 8. M. pudica var. tetrandra

8'. Acúleos fortemente recurvados, internodais, dispostos em fileiras longitudinais; folíolos 2,7-4,8 × 0,8-1,7 cm, lanceolado-falcados; inflorescência com 65-103 flores ...... 10. M. sensitiva var. sensitiva

7'. Nervação hifódroma.

9. Folíolos 12-18 pares; flores pentâmeras; frutos quadrangulares em seção transversal .......................9. M. quadrivalvis var. leptocarpa

9’. Folíolos 4-10 pares; flores trímeras; frutos plano-compressos.
10. Folhas com 2-4(-5) pares de pinas; pecíolo 0,4-0,7 cm compr.; corola 2-3 mm compr., glabra. 6. M. misera

10'. Folhas com apenas um par de pinas; pecíolo 2-4 cm compr.; corola 1,8-2 mm compr., puberulenta .................. 7. M. piscatorum

1. Mimosa acutistipula (Mart.) Benth. var. acutistipula, J. Bot. (Hooker) 4: 391. 1842. Figuras 2a, 3a-f

Arbustos eretos, 3-4 m alt. Tricomas tectores distribuídos nos ramos, estípulas, folíolos, pedúnculos, brácteas e cálice. Ramos cilíndricos, aculeados, acinzentados a nigrescentes com faixas longitudinais mais escuras, puberulentos; acúleos 2-5 mm compr., retos ou recurvados. Estípulas persistentes, 3-6 $\times$ ca. 0,8 mm, subulada-lanceoladas, puberulentas. Folhas com (3-)4-5 pares de pinas, movimentos tigmonásticos discretos; pecíolo $0,7-2 \mathrm{~cm}$ compr.; raque 2,5-3,5 cm compr.; segmentos da raque 0,7-1,4 cm compr.; espículas interpinais ausentes; parafilídios cônicos; folíolos 12-21 pares, 10-12 × 2-2,5 mm, membranáceos, discolores, oblongos, ápice cuneado-mucronado, base oblíqua, margem inteira, puberulentos, nervação camptódroma. Espigas cilíndricas, axilares, terminais, 2-3 × 1-1,4 cm; pedúnculo 0,5-1 cm compr.; brácteas 0,6-1 mm compr., elíptico-oblanceoladas, face abaxial puberulenta, face adaxial glabra, margens ciliadas. Flores tetrâmeras, diplostêmones, sésseis, 146-165 por inflorescência; cálice ca. $0,5 \mathrm{~mm}$ compr., campanulado, brancoesverdeado, piloso; corola 1,8-2 mm compr., campanulada, brancorosada, glabra, lacínias patente-eretas; filetes 3,5-4,5 mm compr., brancos; antera oblongo-ovoide, branco-esverdeada; ovário ca. $1 \mathrm{~mm}$ compr., esbranquiçado, subséssil, glabro; estilete 4,5-6 mm compr., brancos. Craspédios 5-7,5 × 0,8-1 cm, cartáceos, estipitados, planocompressos, 3-9 articulados, lineares, ápice cuneado-mucronado, base cuneada-atenuada, glabros, inermes, marrons; estípite 4-5 mm compr.; artículos quadrangulares, 7-10 × 6-9 mm; replo ligeiramente sinuoso, glabro. Sementes 5-6 $\times$ 4-4,5 mm, ovoides, marrons.

Material examinado: BRASIL, BAHIA: Jeremoabo, APA Serra Branca, Fazenda Serra Branca, 9S 53' 43”, 38W 42' 25”, 375 m, 11/6/2011, D.A.O. Dourado 92, fl., fr. (HUNEB); 11/6/2011, D.A.O. Dourado 93, fl. (HUNEB); 11/6/2011, R.R. Varjão 83, fl. (HUNEB).

Segundo Barneby (1991), Mimosa acutistipula é endêmica do Brasil, ocorrendo em ambientes de caatinga, cerrado e tabuleiro dos estados do Piauí, Pernambuco e Bahia. Barneby (1991) baseado na variação do número de pinas e comprimento das raques das inflorescências reconheceu duas variedades para a espécie: $M$. acutistipula var. acutistipula e M. acutistipula var. ferrea Barneby. $\mathrm{Na}$ APA Serra Branca foi encontrada apenas a variedade acutistipula, formando pequenas populações em áreas abertas, sobre solos arenosos. Popularmente conhecido como jurema-vermelha, $M$. acutistipula var. acutistipula floresce de março a junho e frutifica de maio a agosto.

Dentre as espécies estudadas, assemelha-se morfologicamente a $M$. arenosa var. arenosa e M. tenuiflora, por compartilharem o hábito arbustivo, presença de acúleos nos ramos, flores tetrâmeras, diplostêmones, agrupadas em espigas, filetes brancos e frutos planocompressos. Contudo, M. acutistipula var. acutistipula diferencia-se da primeira por apresentar nervação camptódroma ( $v s$. nervação acródroma); corola branca-rosada ( $v s$. corola branca) e craspédios com 5-7,5 $\times 0,8-1 \mathrm{~cm}(v s .2-5 \times 0,5-0,7 \mathrm{~cm})$. O táxon pode ser diferenciado da segunda espécie pelo ovário glabro (vs. ovário puberulento) e folíolos sem pontuações glandulares na face abaxial (vs. folíolos com pontuações glandulares escuras translúcidas na face abaxial). 

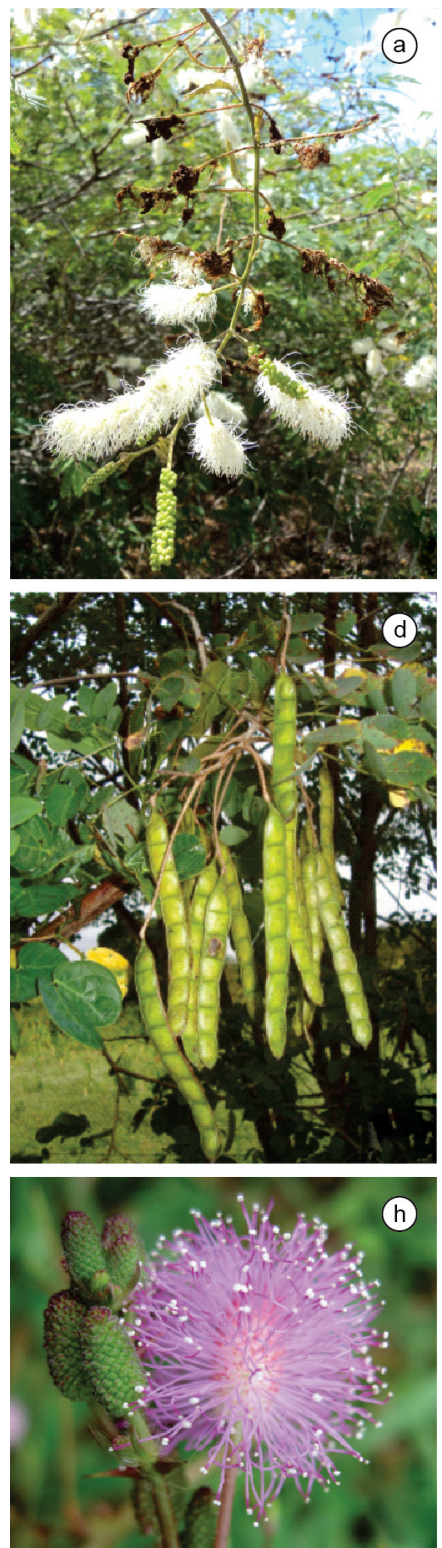
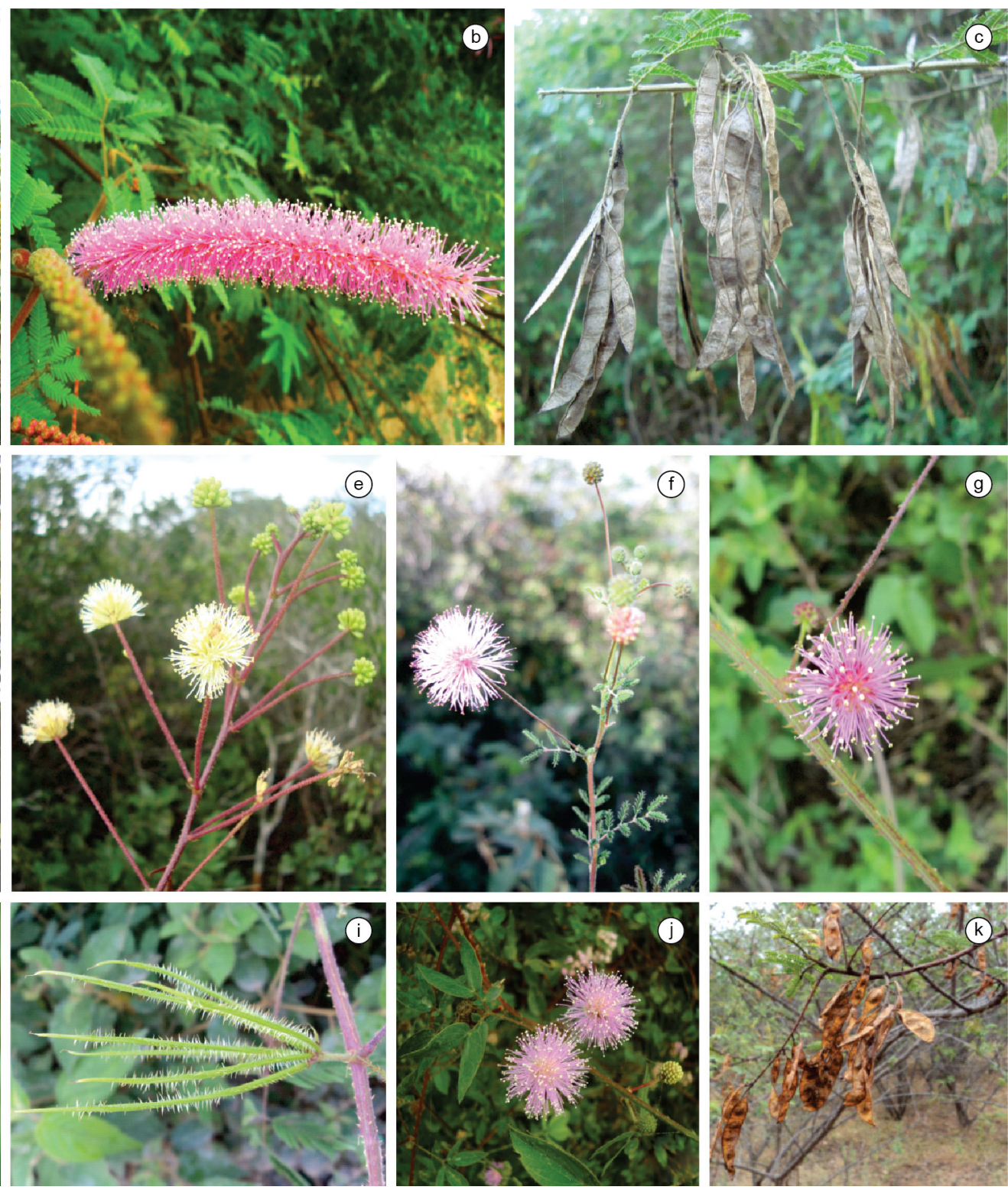

Figura 2. Representantes do gênero Mimosa na APA Serra Branca. a. M. acutistipula (Mart.) Benth. var. acutistipula; b. M. adenophylla Taub. var. mitis Barneby; c. M. arenosa (Willd.) Poir. var. arenosa; d. M. caesalpiniifolia Benth.; e. M. lewisii Barneby; f. M. misera Benth.; g. M. piscatorum Barneby; h. M. pudica L. var. tetrandra (Humb. \& Bonpl. ex Willd.) DC.; i. M. quadrivalvis L. var. leptocarpa (DC.) Barneby; j. M. sensitiva L. var. sensitiva; k. M. tenuiflora (Willd.) Poir.

Figura 2. Representatives of the genus Mimosa in APA Serra Branca. a. M. acutistipula (Mart.) Benth. var. acutistipula; b. M. adenophylla Taub. var. mitis Barneby; c. M. arenosa (Willd.) Poir. var. arenosa; d. M. caesalpiniifolia Benth.; e. M. lewisii Barneby; f. M. misera Benth.; g. M. piscatorum Barneby; h. M. pudica L. var. tetrandra (Humb. \& Bonpl. ex Willd.) DC.; i. M. quadrivalvis L. var. leptocarpa (DC.) Barneby; j. M. sensitiva L. var. sensitiva; k. M. tenuiflora (Willd.) Poir.

2. Mimosa adenophylla var. mitis Barneby, Brittonia 37: 130. 1985. Figuras 2b, 3g-m

Arbustos eretos, 2,5-3 m alt. Tricomas tectores e/ou entremeados com glândulas sésseis distribuídas nos ramos, estípulas, folíolos, pedúnculos, brácteas, cálice, corola, ovário e frutos. Ramos cilíndricos, inermes, marrons, pilosos. Estípulas decíduas, 2-4 $\times$ ca. 0,8 mm, subulada-lanceoladas, pilosas. Folhas com (3-)4-9 pares de pinas; movimentos tigmonásticos ausentes; pecíolo 1-2 cm compr.; raque 2-5,5 cm compr.; segmentos da raque $0,5-1 \mathrm{~cm}$ compr.; espículas interpinais presentes; parafilídios subulados; folíolos 18-35 pares, 4-8 × 1,5-3 mm, membranáceos, discolores, oblongos, ápice arredondado-cuneado, base oblíqua-truncada, margem ciliada, pilosos, face abaxial com pontuações glandulares, resinosas, amareladas, nervação hifódroma. Espigas cilíndricas, solitárias, axilares, terminais, 7-9,5 × 1,5-2 cm; pedúnculo 1,5-2 cm compr.; brácteas $0,6-1 \mathrm{~mm}$, linear-oblanceoladas, face abaxial pilosa, face adaxial glabra, ciliadas no ápice. Flores tetrâmeras, diplostêmones, sésseis, 114-284 por inflorescência; cálice ca. $0,5 \mathrm{~mm}$ compr., campanulado, branco-esverdeado, ciliado, com pontuações glandulares; corola ca. $2 \mathrm{~mm}$ compr., campanulada, branca, glabra, ciliada no ápice das lacíneas, com pontuações glandulares; lacínias patentes; filetes 6-7 mm compr., róseos; antera oblonga, esverdeada; ovário ca. 0,5 mm compr., branco, subséssil, piloso; estilete 3-4 mm compr., rosa-choque. Craspédios 2,5-3,5 × 0,5-0,7 cm, cartáceos, 
Dourado, D.A.O. et al.

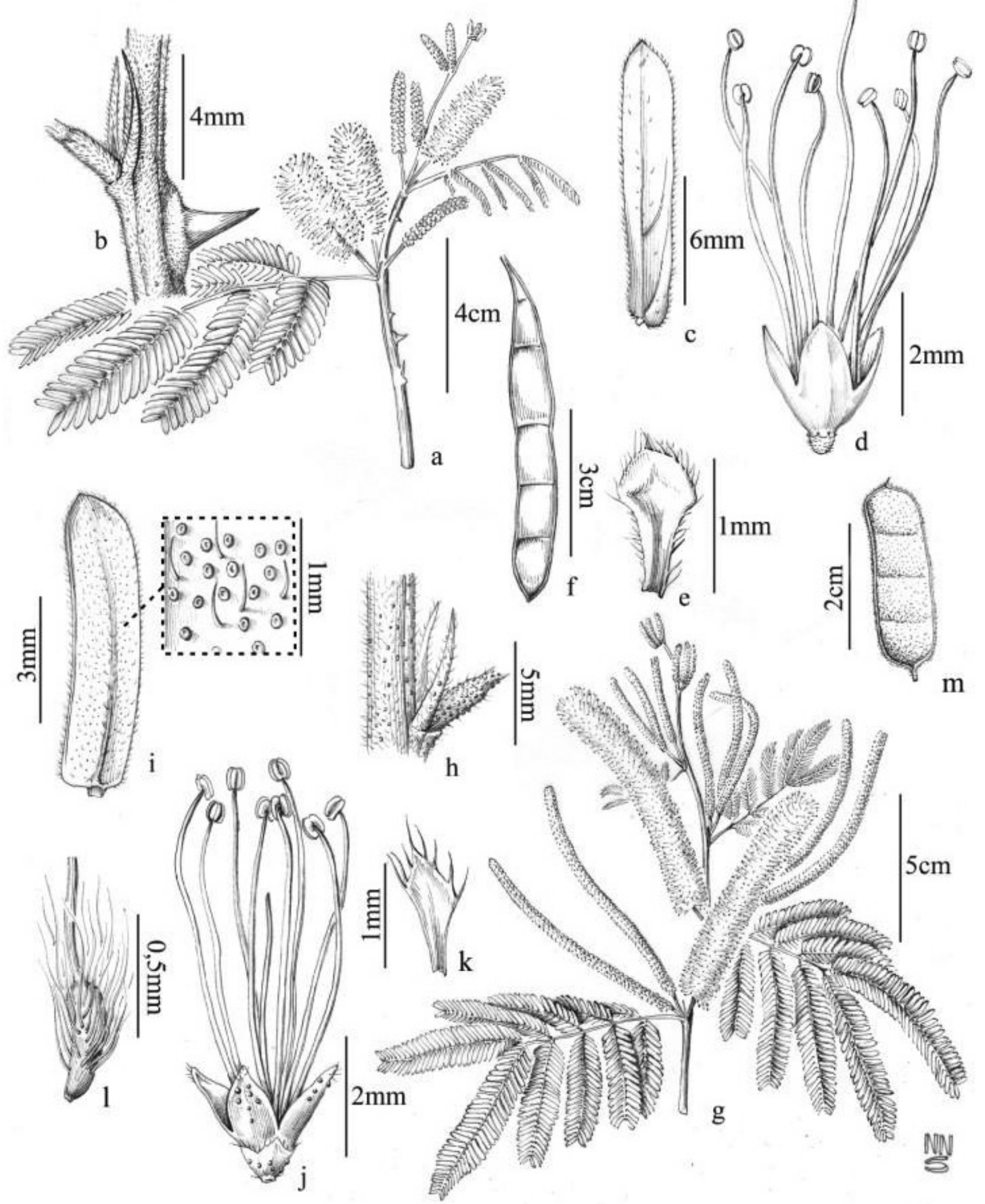

Figura 3. a-f. M. acutistipula (Mart.) Benth. var. acutistipula: a. ramo florido; b. detalhe da estípula e acúleo; c. folíolo, face adaxial; d. flor; e. bráctea, face adaxial; f. fruto. g-m. M. adenophylla Taub. var. mitis Barneby: g. ramo florido; h. estípulas; i. folíolo, face abaxial e detalhes das glândulas; j. flor; k. bráctea, face adaxial; 1. ovário; m. fruto. a-f. D.A.O. Dourado 92; R.R.Varjão 83; g-m. D.A.O. Dourado 84; D.A.O. Dourado 93.

Figure 3. a-f. M. acutistipula (Mart.) Benth. var. acutistipula: a. flowering branch; b. details of the stipule and aculeo; c. leaflet, adaxial surface; d. flower; e. bract, adaxial surface; f. fruit. g-m. M. adenophylla Taub. var. mitis Barneby: g. flowering branch; h. stipules; i. leaflet, abaxial surface and details of the glands; j. flower; k. bract, adaxial surface; 1. ovary; m. fruit. a-f. D.A.O. Dourado 92; R.R.Varjão 83; g-m. D.A.O. Dourado 84; D.A.O. Dourado 93. 


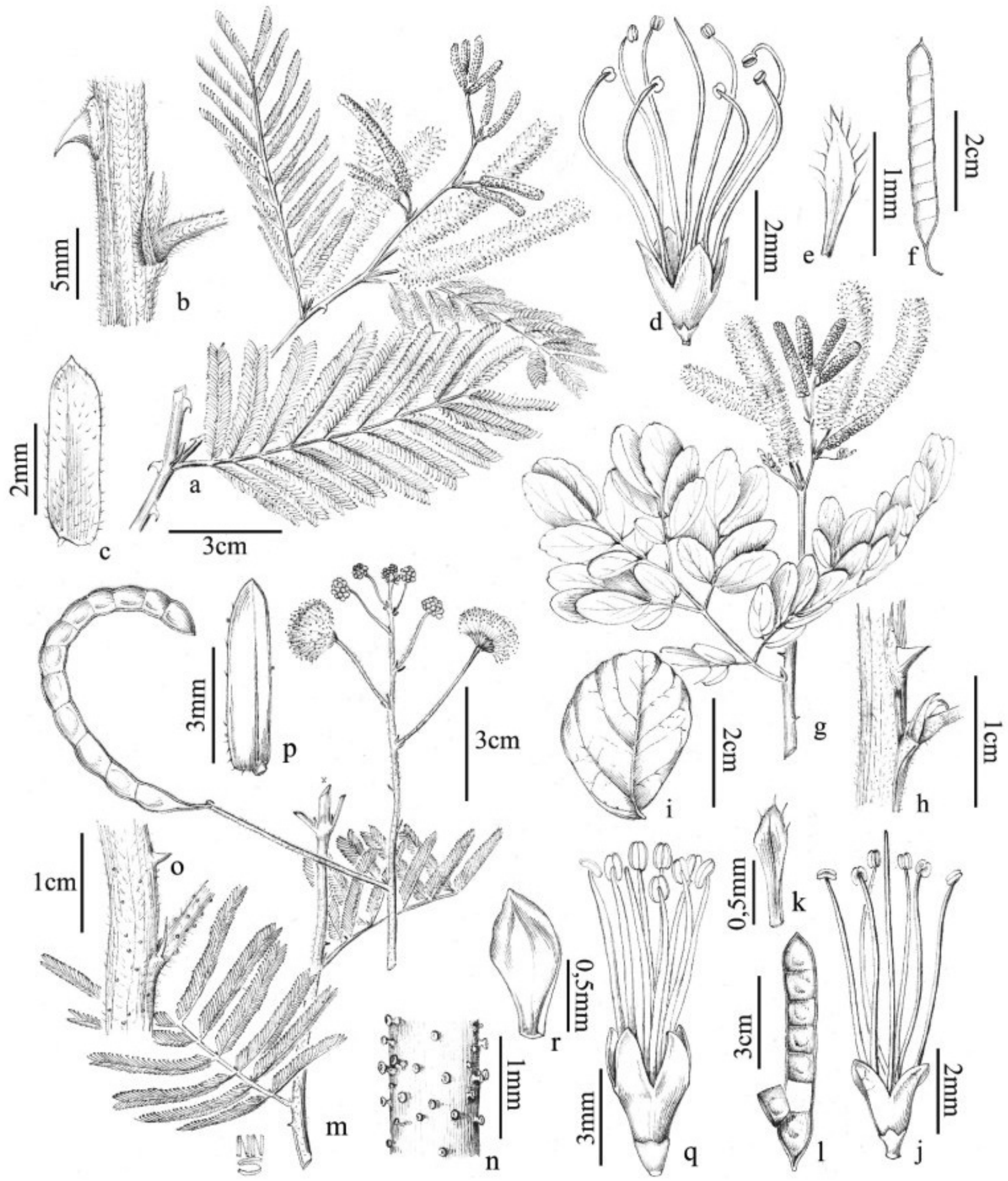

Figura 4. a-f. M. arenosa (Willd.) Poir. var. arenosa: a. ramo florido; b. detalhes das estípulas e acúleo; c. folíolo, face adaxial; d. flor; e. bráctea, face adaxial; f. fruto. g-1. M. caesalpiniifolia Benth.: g. ramo florido; h. detalhes das estípulas e acúleo; i. folíolo, face adaxial; j. flor; k. bráctea, face adaxial; 1. fruto. m-r. M. lewisii Barneby: m. ramo fértil; n. detalhes dos tricomas glandulares no ramo; o. detalhe da estípula e acúleo; p. folíolo, face adaxial; q. flor; r. bráctea, face adaxial. a-f. D.A.O. Dourado 57; g-1. D.A.O. Dourado 59; D.A.O. Dourado 99; m-r. D.A.O. Dourado 77; D.A.O. Dourado 51.

Figure 4. a-f. M. arenosa (Willd.) Poir. var. arenosa: a. flowering branch; b. details of the stipules and aculeo; c. leaflet, adaxial surface; d. flower; e. bract, adaxial surface; f. fruit. g-l. M. caesalpiniifolia Benth.: g. flowering branch; h. details of the stipules and aculeo; i. leaflet, adaxial surface; j. flower; k. bract, adaxial surface; 1. fruit. m-r. M. lewisii Barneby: m. fertile branch; n. details of the glandular trichomes in branch; o. details of the stipule and aculeo; p. leaflet, adaxial surface; q. flower; r. bract, adaxial surface. a-f. D.A.O. Dourado 57; g-1. D.A.O. Dourado 59; D.A.O. Dourado 99; m-r. D.A.O. Dourado 77; D.A.O. Dourado 51. 
estipitados, plano-compressos, 4-6 articulados, lineares, ápice arrendondado-mucronado, base arredondada, pilosos, inermes, marrons; estípite ca. $1 \mathrm{~mm}$ compr.; artículos quadrangulares ca. $5 \times$ $7 \mathrm{~mm}$; replo ligeiramente sinuoso, piloso. Sementes 2-3 $\times 2-3 \mathrm{~mm}$, ovoides, marrons.

Material examinado: BRASIL, BAHIA: Jeremoabo, APA Serra Branca, Entrada da APA, 9S 57' 30", 38W 26' 19”, 524 m, 8/4/2011, D.A.O. Dourado 84, fl. (HUNEB); 10/6/2011, D.A.O. Dourado 85, fl., fr. (HUNEB).

A espécie ocorre em áreas de caatinga e cerrado nos estados do Ceará, Pernambuco e Bahia (Barneby 1985, 1991, Queiroz 2009). São reconhecidas três variedades para a espécie: $M$. adenophylla var. armandiana (Rizzini) Barneby, M. adenophylla var. adenophylla, e M. adenophylla var. mitis Barneby, das quais as duas últimas ocorrem na caatinga (Barneby 1991, Queiroz 2009). Para APA foi catalogada apenas a variedade $M$. adenophylla var. mitis, que é conhecida popularmente como jurema-rosa e se apresenta com baixa frequência, em áreas degradadas mais abertas, ocorrendo em solos areno-argilosos. Foi encontrada com flores de março a junho e frutos de maio a agosto.

Mimosa adenophylla var. mitis distingue-se claramente das demais espécies da APA, por apresentar ramos inermes, pontuações glandulares resinosas amareladas na face abaxial dos folíolos, filetes róseos e o ovário piloso

3. Mimosa arenosa (Willd.) Poir. var. arenosa, Encycl. Suppl. 1: 66. 1810. Figuras $2 \mathrm{c}, 4 \mathrm{a}-\mathrm{f}$

Arbustos eretos, 2-5 m alt. Tricomas tectores distribuídos nos ramos, estípulas, folíolos e pedúnculos. Ramos cilíndricos, inermes ou aculeados, castanhos, tomentosos; acúleos 2-5 mm compr., recurvados. Estípulas persistentes 3-4 × 0,5-1 mm, lanceoladalineares, pubescentes. Folhas com $6-10$ pares de pinas, movimentos tigmonásticos ausentes; pecíolo 0,5-1,5 cm compr.; raque 2,8-7,5 cm compr.; segmento da raque $0,5-1 \mathrm{~cm}$ compr.; espículas interpinais presentes; parafilídios cônicos; folíolos 10-40 pares, 4-6 × 1-1,5 $\mathrm{mm}$, membranáceos, discolores, oblongos, ápice agudo-mucronado, base oblíqua, margem inteira, glabros a puberulentos, nervação acródroma. Espigas cilíndricas, solitárias, axilares ou agrupadas em pseudoracemos terminais, 3,5-5,7 × ca. $2 \mathrm{~cm}$; pedúnculo 0,9-1,4 cm compr.; brácteas ca. $1 \mathrm{~mm}$ compr., linear-elípticas, glabras, margens ciliadas. Flores tetrâmeras, diplostêmones, subsésseis, 124-172 por inflorescência; cálice 0,5-0,8 mm compr., campanulado, brancoesverdeado, glabro; corola ca. $2 \mathrm{~mm}$ compr., campanulada, branca, glabra; lacínias patentes ou reflexas; filetes 5-6 mm compr., brancos; antera oblongo-ovoide, verde-amarelada; ovário ca. $1 \mathrm{~mm}$ compr., branco-esverdeado, subséssil, glabro; estilete 5-6 mm compr., branco. Craspédios (2-)3-5 × 0,5-0,7 cm, cartáceos, estipitados, planocompressos, 6-9 articulados, lineares, ápice agudo-mucronado, base atenuada-cuneada, glabros, inermes, marrons; estípite 4-8 mm compr.; artículos quadrangulares, 5-6 $\times$ 4-5 mm; replo reto, glabro. Sementes 3-5 $\times$ 2,5-3,5 mm, ovoides a elipsoides, marrons.

Material examinado: BRASIL, BAHIA: Jeremoabo, APA Serra Branca, Trilha que vai dos Quelés em direção a Estação Ecológica Raso da Catarina, 9S 53' 1", 38W 32' 39”, 650 m, 22/9/2011, D.A.O. Dourado 56, fr. (HUNEB); 22/9/2011, D.A.O. Dourado 57, fl., fr. (HUNEB); 9S 52' 53”, 38W 32' 42”, 650 m, 22/9/2011, D.A.O. Dourado 64, fr. (HUNEB); 23/9/2011, D.A.O. Dourado 65, fr. (HUNEB); 23/9/2011, D.A.O. Dourado 69, fr. (HUNEB); Entrada da APA, próximo a porteira, 9S 57' 30", 38W 26' 19”, 650 m, 7/9/2011, D.A.O. Dourado 82, fr. (HUNEB); 7/9/2011, D.A.O. Dourado 83, fl., fr. (HUNEB); 1/8/2011, D.A.O. Dourado 115, fl., fr. (HUNEB).

Mimosa arenosa foi referida por Barneby (1991), para a America do Sul (Brasil, Colômbia e Venezuela) e América Central (México).
No Brasil, ocorre do estado do Ceará até Minas Gerais (Barneby 1991, Queiroz 2009, Santos-Silva \& Sales 2008, 2010). De acordo com Barneby (1991), são reconhecidas três variedades para a espécie: $M$. arenosa var. arenosa, M. arenosa var. lysalgica Barneby e $M$. arenosa var. leiocarpa (DC.) Barneby. Na APA Serra Branca esta espécie é representada apenas pela variedade arenosa, que é bastante frequente na área e, conhecida popularmente por diferentes nomes: calumbí, calumbí-de-vaqueiro e jurema-branca. Foi coletada em vegetação mais preservada, mas também ocorre em áreas degradadas, sobre solos arenosos e areno-argilosos. Floresce de abril a setembro e frutifica de julho a novembro.

Mimosa arenosa var. arenosa é facilmente diagnosticada pelas amplas panículas terminais de flores brancas, que normalmente excedem ca. $20 \mathrm{~cm}$ as folhagens. Os frutos são plano-compressos e estipitados, características também compartilhadas por outros táxons do gênero, a exemplo, M. acutistipula var. acutistipula. No entanto, este último táxon diferencia-se principalmente pelo número de pinas (3-5 pares vs. 6-10 pares em M. arenosa) e folíolos (12-21 pares $v s$. 10-40 pares).

4. Mimosa caesalpiniifolia Benth., J. Bot. (Hooker) 4: 392. 1841. Figuras 2d, 4g-1

Arbustos eretos, 4-6 m alt. Tricomas tectores distribuídos nos ramos, estípulas, brácteas e margem do ovário. Ramos cilíndricos, aculeados, castanhos a acinzentados, pilosos; acúleos 4-8 mm compr., recurvados. Estípulas persistentes 4-6 × 0,8-1 mm, lanceoladas, pilosas. Folhas com 2-3 pares de pinas; movimentos tigmonásticos ausentes; pecíolo 1-7 cm compr.; raque 4-12 cm compr.; segmentos da raque 1,5-4 cm compr.; espículas interpinais presentes; parafilídios subulados; folíolos 2-4 pares, (25-)40-90 × (20-)25-40 mm, membranáceos a subcoriáceos, oval-obovais, ápice arredondado, base oblíqua-arredondada, margem levemente crenada, glabros, nervação craspedódroma. Espigas cilíndricas, solitárias ou 2-fasciculadas, axilares, terminais, 5-8 $\times 2-3 \mathrm{~cm}$; pedúnculo $5-8 \mathrm{~mm}$ compr.; brácteas 0,7-1 mm compr., linear-oblanceoladas, glabras, ápice ciliados. Flores trímeras, diplostêmones, sésseis, 130-161 por inflorescência; cálice 0,4-0,5 mm compr., campanulado, branco-esverdeado, glabro; corola ca. $2 \mathrm{~mm}$, campanulada, branco-esverdeada, glabra; lacínias patentes; filetes 5-7 mm compr., brancos; antera oblongo-ovoide, marrom; ovário ca. $1 \mathrm{~mm}$ compr., branco-esverdeado, subséssil, glabro; estilete 5,4-7 mm compr., branco. Craspédios 6-9 × 1-1,6 cm, coriáceos, estipitados, plano-compressos, 7-8 articulados, lineares, ápice cuneado-mucronado, base cuneada-arredondada, glabros, inermes, marrons; estípite 3-10 mm compr.; artículos quadrangulares, 6-9 $\times$ 8-13 mm; replo ligeiramente sinuoso, glabro. Sementes, 5-5,5 $\times$ 4-4,5 mm, obovoide-oblongoides, castanho-claras.

Material examinado: BRASIL, BAHIA: Jeremoabo, APA Serra Branca, Trilha que vai dos Quelés em direção a Estação Ecológica Raso da Catarina, próximo a entrada da APA, 9S 53' 1', 38W 32' 39”, 650 m, 22/9/2010, D.A.O. Dourado 59, fr. (HUNEB); Trilha que vai dos Quelés em direção a Estação Ecológica Raso da Catarina, 9S 57' 25”, 38W 26' 79', 500 m, 12/6/2011, D.A.O. Dourado 99, fl. (HUNEB).

Mimosa caesalpiniifolia é uma espécie endêmica do Brasil, registrada do estado de Pernambuco até o Maranhão (Barneby 1991, Queiroz 2009, Santos-Silva \& Sales 2008, 2010). Na APA Serra Branca, a espécie é pouco frequente e foi provavelmente introduzida, sendo observada em áreas degradadas abertas, sobre solo arenoso e areno-argiloso. É conhecida popularmente como sabiá, encontrada com flores de abril a junho e frutos de junho a setembro.

As folhas com 2-3 pares de pinas e 2-4 pares folíolos, o tamanho amplo dos folíolos (25-)40-90 × (20-)25-40 mm com nervação 
craspedódroma, filetes brancos e os frutos estipitados, a distinguem das demais espécies que ocorrem na área.

\section{Mimosa lewisii Barneby, Brittonia 37: 136. 1985. Figuras 2e, 4m-r}

Arbustos eretos, 1-3 m alt. Tricomas glandulares e/ou tectores, distribuídos nos ramos, estípulas, pecíolo, margem dos folíolos, raque, pedúnculos e frutos. Ramos cilíndricos, aculeados, verdeavermelhados, pubescente-puberulentos; acúleos 2-6 mm compr., retos ou discretamente recurvados. Estípulas persistentes, 2,5-4 $\times$ 0,8-1,5 mm, espinescentes, pubescentes. Folhas com (6-)8-10(-12) pares de pinas; movimentos tigmonásticos ausentes; pecíolo $0,3-2 \mathrm{~cm}$ compr.; raque 1-6,8 cm compr.; segmentos da raque $0,4-1 \mathrm{~cm}$ compr.; espículas interpinais presentes; parafilídios cilíndricos; folíolos 25 54 pares, 4-5 × 1-1,5 mm, cartáceos, discolores, oblongos, ápice arredondado, base oblíqua, margem inteira, glabros, com tricomas tectores e glandulares presentes nas margens, nervação hifódroma. Glomérulos agrupados em pseudoracemos terminais ultrapassando a folhagem, 1-1,7 cm diâm.; pedúnculo 2,5-5 cm compr.; brácteas 1,5-2 mm compr., espinescentes, glabras. Flores tetrâmeras, diplostêmones, sésseis, 14-22 por inflorescência; cálice ca. $2 \times 2 \mathrm{~mm}$ compr., campanulado, branco-esverdeado, glabro; corola 4-5,5 mm compr., campanulada, branco-esverdeada, glabra; lacínias eretas; filetes 4-5 mm compr., brancos, antera oblongo-ovoide, esverdeada; ovário ca. 1,9 mm compr., branco-esverdeado, séssil, glabro; estilete 4-5 mm compr., branco. Craspédios 4,4-9,8 × 0,7-0,8 cm, cartáceos, curtamente estipitados, plano-compressos, 8-12 articulados, lineares a oblongos ligeiramente recurvados, ápice cuneado-mucronado, base aguda-cuneada, puberulentos com tricomas glandulares esparsos, inermes, marrom-escuros; estípite 2-3 $\mathrm{mm}$; artículos quadrangulares, 7-8 $\times$ 5-6 mm; replo ligeiramente ondulado, glabro. Sementes ca. 6 $\times 4,5 \mathrm{~mm}$, elipsoides, marrons.

Material examinado: BRASIL, BAHIA: Jeremoabo, APA Serra Branca, Trilha que vai dos Quelés em direção a Estação Ecológica Raso da Catarina, 9S 53' 1', 38W 32'39”, 650 m, 22/9/2010, D.A.O. Dourado 51, fl. (HUNEB); 4/12/2010, D.A.O. Dourado 77, fr. (HUNEB); 12/6/2011, D.A.O. Dourado 97, fl., fr. (HUNEB).

Mimosa lewisii é endêmica do nordeste brasileiro (Barneby 1985, 1991, Lewis 1987), onde ocorre nos estados de Pernambuco e Bahia, em áreas de campo rupestre, caatinga e dunas litorâneas (Barneby 1991, Queiroz 2009, Santos-Silva \& Sales 2008, 2010). Esta espécie é bastante frequente na APA, conhecida popularmente como jureminha, ocorrendo em áreas preservadas e degradadas, abertas e fechadas sobre solos arenosos. Floresce e frutifica de janeiro a dezembro.

Caracteriza-se principalmente pelas estípulas espinescentes, folhas com 6-12 pares de pinas, folíolos cartáceos, pseudoracemos terminais ultrapassando a folhagem e frutos com 4,4-9,8 cm, sendo este o maior comprimento observado entre as espécies estudadas. Em campo é facilmente identificada pelos pseudoracemos terminais, que ultrapassam a folhagem até $30 \mathrm{~cm}$ de comprimento.

6. Mimosa misera Benth., J. Bot. (Hooker) 4: 411. 1842. Figuras 2f, $5 a-f$

Subarbustos prostrados a decumbentes, 0,2-0,4 $\mathrm{m}$ alt. Tricomas glandulares nas margens e face abaxial dos folíolos, na raque e pedúnculos. Ramos cilíndricos, inermes a raramente aculeados, verde-avermelhados, vilosos; acúleos ca. 0,4 mm compr., retos ou recurvados. Estípulas persistentes, 2-3 × 1-1,5 mm, lanceoladoovais, ciliadas. Folhas com 2-4(-5) pares de pinas; movimentos tigmonásticos discretos; pecíolo $0,4-0,7 \mathrm{~cm}$ compr.; raque 0,5 $1,9 \mathrm{~cm}$ compr.; segmentos da raque ca. $0,4 \mathrm{~cm}$ compr.; espículas interpinais ausentes; parafilídios ausentes; folíolos (4-)6-8 pares, 2-3 × 1-1,5 mm, cartáceos, discolores, oblongos, ápice arredondado, base oblíqua, margem esparsamente ciliada, indumento adaxial glabro, indumento abaxial pubescente, margens revestidas por tricomas glandulares, nervação hifódroma. Glomérulos solitários, axilares, 1,5-1,7 cm diâm.; pedúnculo 3-4 cm compr.; brácteas 0,5$1 \mathrm{~mm}$ compr., linear-oblanceoladas, glabras, ápice ciliados. Flores trímeras, diplostêmones, sésseis, 44-58 por inflorescência; cálice ca. 0,4 mm compr., campanulado, verde, glabro; corola 2-3 mm compr., campanulada, rósea, glabra; lacínias eretas; filetes 5-6 mm compr., róseos; antera oblongo-ovoide, verde-amarelada; ovário 1-1,4 mm compr., séssil glabro; estilete 4,8-5,8 mm compr., róseo. Craspédios 1,5-2 × ca. 0,4 cm, cartáceos, curtamente estipitados, plano-compressos, 2-8 articulados, elíptico-oblongos, ápice agudocuneado, base cuneada-atenuada, puberulento-escabrosos, armados com tricomas rígidos radiais, castanho claros; estípite $1 \mathrm{~mm}$; artículos quadrados, 3-4 × 3-4 mm; replo ondulado, piloso. Sementes ca. $2 \times$ 2,5 mm, oblongoides, marrons.

Material examinado: BRASIL, BAHIA: Jeremoabo, APA Serra Branca, Trilha que vai dos Quelés em direção a Estação Ecológica Raso da Catarina, 9S 56' 45", 38W 27' 31”, 607 m, 29/7/2009, A.S. Conceição 1817, fl., fr. (HUNEB); 9S 56' 23”, 38W 28' 6”, 631 m, 23/9/2010, fr., D.A.O. Dourado 62 (HUNEB); 5/11/2010, D.A.O. Dourado 76, fl. (HUNEB); 9S 53' 2", 38W 32' 39”, 625 m, 4/12/2010, D.A.O. Dourado 78, fl., fr., (HUNEB); 4/12/2010, D.A.O. Dourado 79, fl. (HUNEB); 9S 57' 30”, 38W 26' 19”, 650 m, 7/4/2011, D.A.O. Dourado 87, fl. (HUNEB).

Mimosa misera é endêmica do nordeste brasileiro, ocorrendo nos estados da Bahia, Ceará, Pernambuco e Piauí (Lewis 1987, Barneby 1991, Queiroz 2009, Santos-Silva \& Sales 2008, 2010). Barneby (1991) reconheceu duas variedades para a espécie: $M$. misera var. misera Benth. e M. misera var. subinermis (Benth.) Barneby, baseando-se principalmente no tamanho e número de pinas e na presença ou ausência de acúleos nos ramos. Bentham (1841) considerou M. misera como uma "espécie imperfeita", mas não justificou sua afirmação. Barneby (1991) reconheceu a espécie como "amorfa" e "indeterminada". Segundo Queiroz (2009) M. misera é uma espécie muito variável em diversos caracteres, com grande sobreposição e variação local, parte da variação pode ser observada dentro de algumas populações, podendo estar relacionada ao desenvolvimento da planta. Nesse trabalho reconhecemos a espécie como um táxon bastante variável e, por esse motivo, decidimos não reconhecer aqui variedades. Na área de estudo, $M$. misera é uma espécie bastante frequente, ocorrendo em áreas degradadas abertas de vegetação arbustiva, próximo as trilhas e áreas antropizadas, em solos arenosos. É conhecida popularmente como malícia de boi. Foi coletada com flores e frutos entre os meses de fevereiro e dezembro.

Mimosa misera diferencia-se das demais espécies estudadas, por apresentar hábito subarbustivo de pequeno porte $(20-40 \mathrm{~cm})$, folíolos de tamanho bastante reduzido $(2-3 \times 1-1,5 \mathrm{~mm})$ e flores trímeras, diplostêmones.

7. Mimosa piscatorum Barneby, Mem. New York Bot. Gard. 65: 286. 1991. Figuras 2g, 5g-1

Subarbustos prostrados a escandentes, 1-1,5 m alt. Tricomas tectores presentes nos ramos, estípulas, folíolos, pedúnculos, brácteas, cálice, corola, ovário e frutos. Ramos cilíndricos, verdeavermelhados, aculeados, puberulentos; acúleos 0,5-1 mm compr., recurvados. Estípulas persistentes, 2-3(-4) mm compr., subuladas, puberulentas. Folhas com 1 par de pinas, movimentos tigmonásticos rápidos; pecíolo 2-4 cm compr.; raque ausente; segmentos da raque ausentes; espículas interpinais presentes; parafilídios linear-oblongos; folíolos 8-10 pares, 7,5-9 × 2,5-4 mm, membranáceos, discolores, oblongos, ápice arredondado-agudo, base oblíqua, margem inteira, puberulentos, nervação hifódroma. Glomérulos solitários, axilares, ca. 1,5 cm diâm.; pedúnculo 0,5-1,5 cm compr.; brácteas ca. $1 \mathrm{~mm}$ 


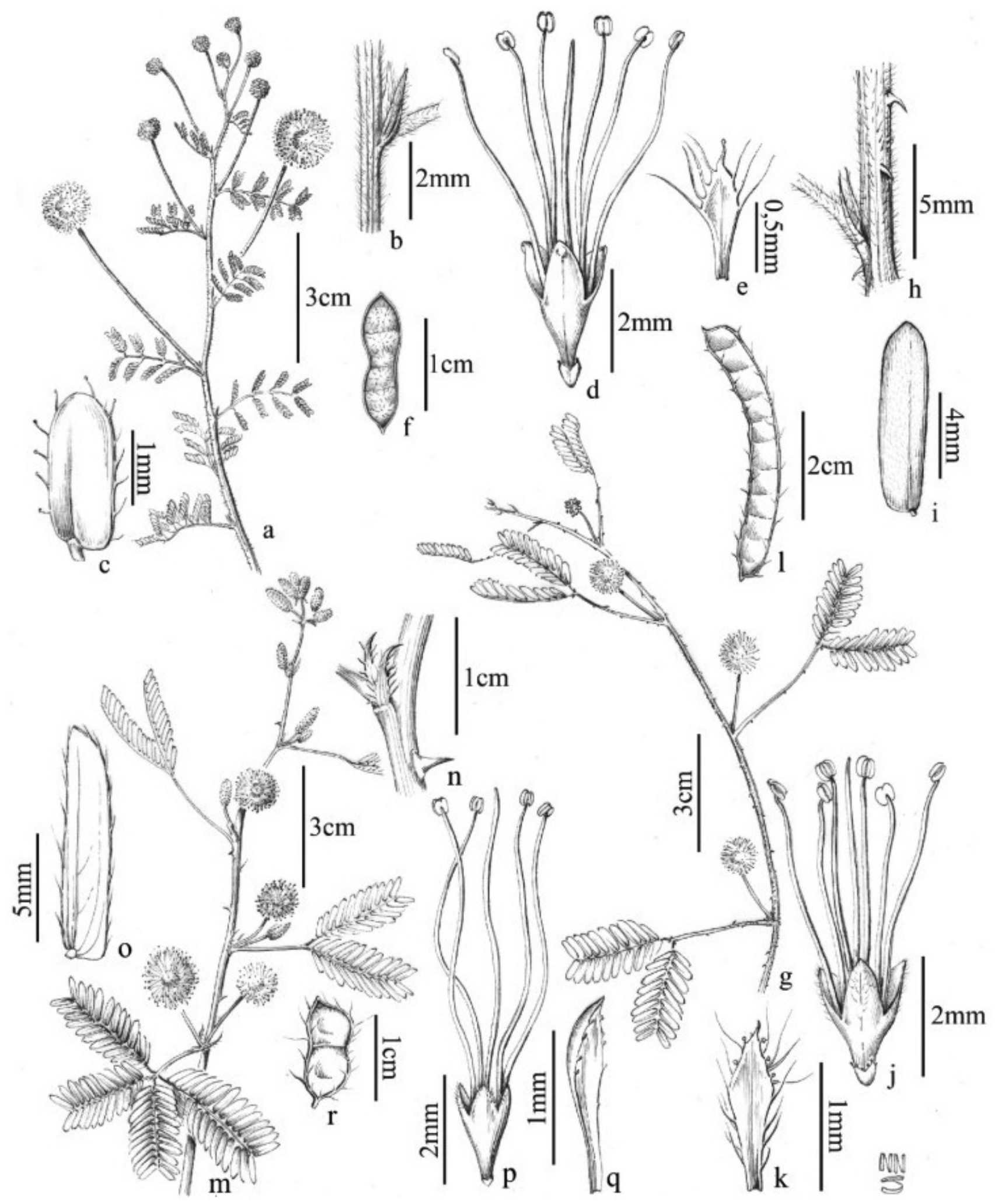

Figura 5. a-f. M. misera Benth.: a. ramo florido; b. detalhes das estípulas; c. folíolo, face adaxial; d. flor; e. bráctea, face adaxial; f. fruto. g-l. M. piscatorum Barneby: g. ramo florido; h. detalhes das estípulas e acúleos; i. folíolo, face adaxial; j. flor; k. bráctea, face adaxial; 1. fruto. m-r. M. pudica L. var. tetrandra (Humb. \& Bonpl. ex Willd.) DC.: m. ramo florido; n. detalhes das estípulas e acúleo; o. folíolo, face adaxial; p. flor; q. bráctea, face adaxial; r. fruto. a-f. A.S. Conceição 307; g-1. D.A.O. Dourado 101; D.A.O. Dourado 63; m-r. D.A.O. Dourado 54.

Figure 5. a-f. M. misera Benth.: a. flowering branch; b. details of the stipules; c. leaflet, adaxial surface; d. flower; e. bract, adaxial surface; f. fruit. g-1. M. piscatorum Barneby: g. flowering branch; h. details of the stipules and aculei; i. leaflet, adaxial surface; j. flower; k. bract, adaxial surface; 1 . fruit. m-r. $M$. pudica L. var. tetrandra (Humb. \& Bonpl. ex Willd.) DC.: m. flowering branch; n. details of the stipules and aculeo; o. leaflet, adaxial surface; p. flower; q. bract, adaxial surface; r. fruit. a-f. A.S. Conceição 1817; g-1. D.A.O. Dourado 101; D.A.O. Dourado 63; m-r. D.A.O. Dourado 54. 
compr., elíptico-oblanceoladas, face abaxial puberulenta, face adaxial glabra, margens ciliadas. Flores trímeras, diplostêmones, sésseis, 18-20 por inflorescência; cálice 0,5-0,6 mm compr., campanulado, verde, ciliado; corola 1,8-2 mm compr., campanulada, verde clara com máculas róseo-avermelhadas, puberulenta; lacínias eretas; filetes 3,5-4(-5) mm compr., róseos; antera oblonga, verde-amarelada; ovário 0,6-0,8 mm compr., séssil, glabro ou puberulento, estilete 3,7-4,4(-5) mm compr., róseo. Craspédios 3-4(-4,8) × 0,4(-0,5) cm, cartáceos, sésseis, plano-compressos, 3-11 articulados, lineares, ápice mucronado-cuneado, base cuneada-atenuada, castanhos, pilosos, armados com acúleos recurvados, subulados; artículos quadrangulares, 3-4 × 3-4 mm; replo levemente ondulado, piloso. Sementes 2-3 × 1,4-2 mm, obovoide-elipsoides, marrons.

Material examinado: BRASIL, BAHIA: Jeremoabo, APA Serra Branca, Trilha que vai dos Quelés em direção a Estação Ecológica Raso da Catarina, 9S 52' 53", 38W 32' 42", 650 m, 23/9/2010, D.A.O. Dourado 63, fl., fr. (HUNEB); 9S 56' 39", 38W 28' 10", 625 m, 5/11/2011, D.A.O. Dourado 73, fr. (HUNEB); 16/6/2011, D.A.O. Dourado 100, fl. (HUNEB); 9S 57' 22", 38W 26' 56", 510 m, 2/8/2011, D.A.O. Dourado 101, fl., fr. (HUNEB).

Mimosa piscatorum apresenta distribuição disjunta entre a Venezuela e nordeste do Brasil. Em território brasileiro é verificada nos estados de Pernambuco e Bahia (Barneby 1991). A espécie é frequente na APA Serra Branca, ocorrendo principalmente em áreas degradadas abertas, próxima as trilhas, em solos arenosos. Foi coletada com flores de maio a outubro e com frutos de junho a dezembro. É conhecida popularmente como malícia.

$\mathrm{Na}$ área de estudo, $M$. piscatorum assemelha-se a $M$. pudica var. tetrandra, por ambas compartilharem o hábito subarbustivo prostrado a escandente, presença de acúleos nos ramos, movimentos tigmonásticos rápidos, flores agrupadas em glomérulos e filetes róseos. No entanto, $M$. piscatorum diferencia-se de $M$. pudica var. tetrandra por apresentar flores trímeras e diplostêmones ( $v s$. flores tetrâmeras e isostêmones).

8. Mimosa pudica var. tetrandra (Humb. \& Bonpl. ex Willd.) DC., Prodr. 2: 426. 1825. Figuras 2h, 5m-r

Subarbustos prostrados a escandentes, 0,4-0,6 m alt. Tricomas tectores distribuídos nos ramos, estípulas, folíolos, pedúnculos e corola. Ramos cilíndricos, aculeados, verdes, híspidos a subglabros; acúleos 2-5 mm compr., retos, infranodais, distribuídos aos pares. Estípulas persistentes, 3-6 × 0,7-1 mm; lanceolada-ovais, glabras. Folhas com (1-)2 pares de pinas; movimentos tigmonásticos rápidos; pecíolo 1,5-4,5 cm compr.; raque ca. 0,1 cm compr.; segmentos da raque 0,1-0,2 cm compr.; espículas interpinais presentes; parafilídios ovais; folíolos 11-17 pares, 5-9 × 1-2 mm, membranáceos, concolores, linear-oblongos, ápice agudo-mucronado, base oblíquatruncada, margem inteira, glabros a ligeiramente estrigosos, nervação broquidódroma. Glomérulos axilares ou terminais, 0,8-1 cm diâm; pedúnculo ca. $1 \mathrm{~cm}$ compr.; brácteas 1-1,4 mm compr., linear-oblanceoladas, glabras, margens levemente ciliadas. Flores tetrâmeras, isostêmones, sésseis, $108-128$ por inflorescência; cálice campanulado diminuto, menor que $0,5 \mathrm{~mm}$ compr., esverdeado, glabro; corola 1,5-1,7 mm compr., campanulada, róseo-lilás, glabra com as lacínias levemente puberulentas; lacínias eretas; filetes 5-6 mm compr., róseos; antera globosa, esverdeada; ovário ca. $0,5 \mathrm{~mm}$ compr., subséssil, glabro, estilete 5-6 mm compr., róseo. Craspédios 0,8-1 $\times$ ca. $0,5 \mathrm{~cm}$, subcoriáceos, sésseis, plano-compressos, 2-3 articulados, oblongos, ápice cuspidado-mucronado, base arredondada, glabrohíspidos, marrom-claros; artículos quadrangulares, 2-3,5 × 2-3,5 mm; replo ondulado, armado com longas setas, híspido. Sementes 2,5-3 $\times$ 2-2,6 mm, elipsoide-oblongoides, castanho-claro.
Material examinado: BRASIL, BAHIA: Jeremoabo, APA Serra Branca, Trilha que vai dos Quelés em direção a Estação Ecológica Raso da Catarina, próximo a entrada da APA, 9S 53' 1', 38W 32' 39", 650 m, 22/9/2010, D.A.O. Dourado 54, fr. (HUNEB); Fazenda Serra Branca, estrada principal, 9S 53' 43”, 38W 42' 25”, 375 m, 7/4/2011, D.A.O. Dourado 86, fl., fr. (HUNEB); 16/6/2011, D.A.O. Dourado 112, fl., fr. (HUNEB).

De acordo com Barneby (1991), Mimosa pudica ocorre na América do Norte e América do Sul, apesar de ser uma espécie natural da África e Ásia. Barneby (1991) reconheceu cinco variedades para a espécie, baseando-se principalmente no tamanho das estípulas e brácteas e no indumento da corola: M. pudica var. hispida Brenan, M. pudica var. tetrandra (Humb. \& Bonpl. ex Willd.) DC., M. pudica var. pastoris Barneby, M. pudica var. pudica e M. pudica var. unijuga (Walp. \& Duchass.) Griseb. Na área de estudo, apenas a var. tetrandra é observada, onde é conhecida popularmente como malícia. Foi coletado em áreas degradadas, antropizadas, ao longo das trilhas, em solo arenoso e areno-argiloso. Flores e frutos foram observados nos meses de abril e setembro.

$\mathrm{Na}$ área de estudo, o táxon pode ser confundido com $M$. piscatorum (ver comentários em M. piscatorum). A espécie pode ser reconhecida na área pela combinação dos seguintes caracteres: ramos com acúleos retos, folhas com (1-)2 pares de pinas, movimentos tigmonásticos rápidos, folíolos com 5-9 × 1-2 mm, flores tetrâmeras e isostêmones.

\section{Mimosa quadrivalvis var. leptocarpa (DC.) Barneby, Mem. New} York Bot. Gard. 65: 298. 1991. Figuras 2i, 6a-g

Subarbustos prostrados a escandentes, 0,2-0,5 m alt. Tricomas tectores distribuídos nos ramos, estípulas, folíolos, pedúnculos e frutos. Ramos costados, tetragonais, aculeados, verdes, glabropuberulentos; acúleos 1-2 mm compr., recurvados. Estípulas persistentes $4-5 \times$ ca. $0,7 \mathrm{~mm}$, lanceolada-lineares, pubescentes. Folhas com 2(-3) pares de pinas; movimentos tigmonásticos rápidos; pecíolo 1,5-5,5 cm compr.; raque 1-3,5 cm compr.; segmentos da raque $0,7-1,7 \mathrm{~cm}$ compr.; espículas interpinais presentes; parafilídios cônicos; folíolos 12-18 pares, 1-1,4 mm compr., membranáceos, concolores, linear-oblongos, ápice agudo-mucronado, base atenuadaoblíqua, margem inteira, fase abaxial glabra, fase adaxial puberulenta, nervação hifódroma. Glomérulos axilares, 1-1,4 cm diâm.; pedúnculo 1-1,4 cm compr.; brácteas $0,8-1 \mathrm{~mm}$ compr., linear-oblanceoladas, glabras. Flores pentâmeras, diplostêmones, sésseis, 22-25 por inflorescência; cálice ca. $0,5 \mathrm{~mm}$ compr., campanulado, verde, glabro; corola 2,5-3 mm compr., campanulada, branca, glabra; lacínias eretas; filetes 4-6 mm compr., róseos; antera oblongo-ovoide, verdeamarelada; ovário ca. $1 \mathrm{~mm}$ compr., verde-amarelado, subséssil, glabro, estilete 3,8-5,5 mm compr., róseo. Frutos (6-)8-15 × 0,4 cm, cartáceos, sésseis, quadrangulares em seção transversal, lineares, ápice estreitamente atenuado, base aguda, hirsutos, castanhos; valvas contínuas, não dividindo em artículos monospérmicos; replo espesso, glabro, aculeado; acúleos subulados. Sementes 2-4 × 1-2 mm, elipsoides, cinzas.

Material examinado: BRASIL, BAHIA: Jeremoabo, APA Serra Branca, Trilha que vai dos Quelés em direção a Estação Ecológica Raso da Catarina, 9S 53' 1', 38W 32'39”, 650 m, 22/9/2010, D.A.O. Dourado 55, fr. (HUNEB); Entrada da APA, 9S 57'30", 38W 26' 19", 513 m, 12/6/2011, D.A.O. Dourado 96, fl. (HUNEB); Trilha que vai dos Quelés em direção a Estação Ecológica Raso da Catarina, próximo a entrada da APA, 9S 57' 22”, 38W 26' 56", 510 m, 16/6/2011, D.A.O. Dourado 103, fl., fr. (HUNEB).

Mimosa quadrivalvis é amplamente distribuída na América tropical e subtropical (Barneby 1991). No Brasil, ocorre principalmente nos estados de Minas Gerais e Bahia. Para essa espécie foram 
Dourado, D.A.O. et al.

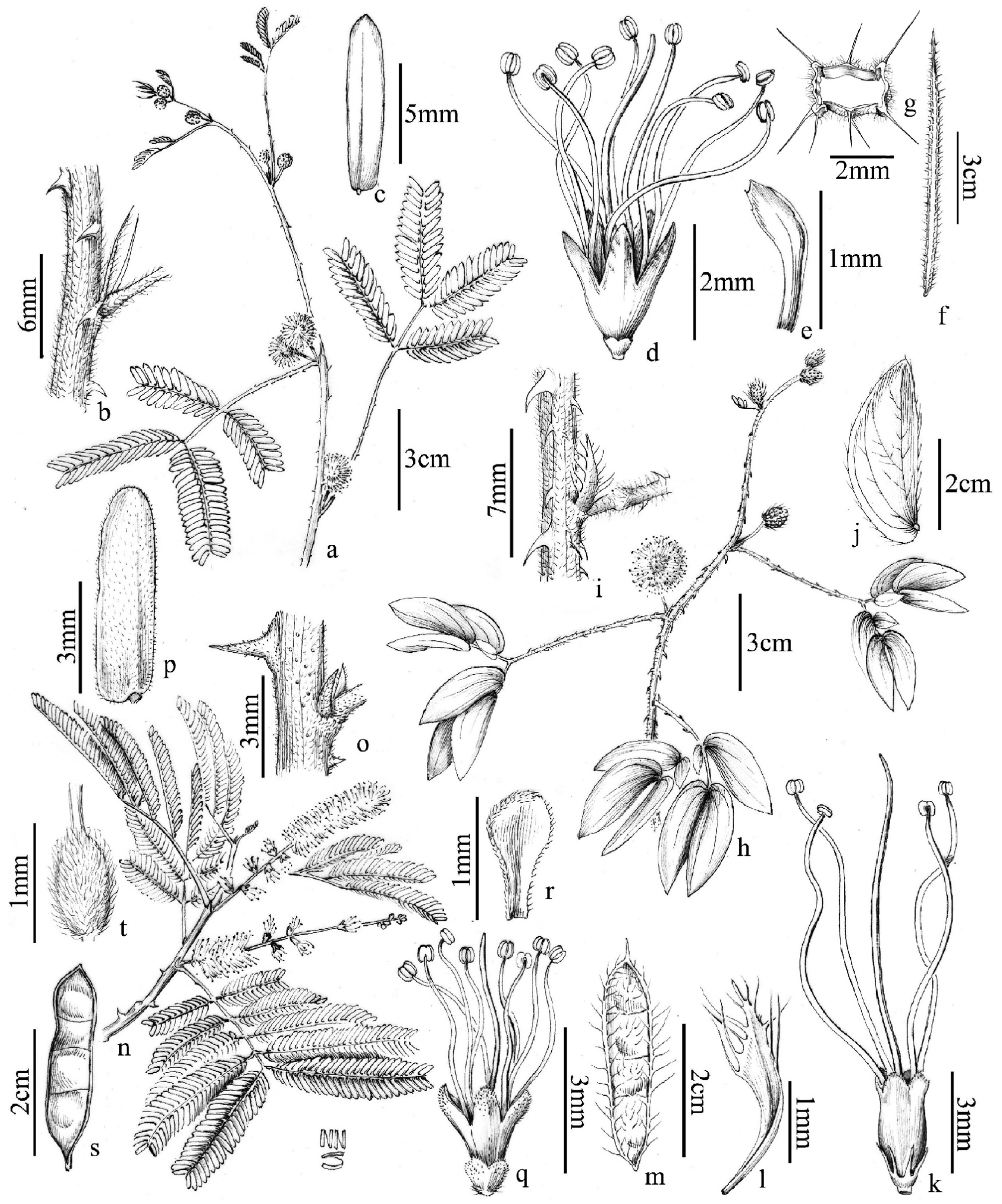

Figura 6. a-g. M. quadrivalvis L. var. leptocarpa (DC.) Barneby: a. ramo florido; b. detalhes das estípulas e acúleos; c. folíolo, face adaxial; d. flor; e. bráctea, face adaxial; f. fruto; g. corte transversal do fruto. h-m. M. sensitiva L. var. sensitiva: h. ramo florido; i. detalhes das estípulas e acúleos; j. folíolo, face adaxial; k. flor; 1. bráctea, face adaxial; m) fruto. n-t. M. tenuiflora (Willd.) Poir.: n. ramo florido; o. detalhes das estípulas e acúleos; p. folíolo, face abaxial; q. flor; r. bráctea, face adaxial; s. fruto; t. ovário. a-g. D.A.O. Dourado 55; D.A.O. Dourado 103; h-m. D.A.O. Dourado 91; n-t. D.D. Vieira 16; D.A.O. Dourado 80.

Figure 6. a-g. M. quadrivalvis L. var. leptocarpa (DC.) Barneby: a) flowering branch; b. details of the stipules and aculei; c. leaflet, adaxial surface; d. flower; e. bract, adaxial surface; f. fruit; g. transversal cutting of the fruit. h-m. M. sensitiva L. var. sensitiva: h. flowering branch; i. details of the stipules and aculei; j. leaflet, abaxial surface; k. flower; 1. bract, adaxial surface; m. fruit. n-t. M. tenuiflora (Willd.) Poir.: n. flowering branch; o. details of the stipules and aculei; p. leaflet, abaxial surface; q. flower; r. bract, adaxial surface; s. fruit; t. ovary. a-g. D.A.O. Dourado 55; D.A.O. Dourado 103; h-m. D.A.O. Dourado 91; n-t. D.D. Vieira 16; D.A.O. Dourado 80. 
reconhecidas 16 variedades, baseado principalmente no número de pinas, tamanho do pedúnculo e na morfologia do fruto. Dentre essas variedades, apenas M. quadrivalvis var. leptocarpa ocorre na APA, em áreas degradadas, antropizadas, ao longo das trilhas, em solo arenoso. É conhecida popularmente como malícia e foi coletada com flores de abril a julho e com frutos de julho a outubro.

Esse táxon pode ser facilmente identificado na área, por ser a única espécie que possui fruto séssil, quadrangular em seção transversal, com valvas contínuas, não dividindo em artículos monospérmicos.

10. Mimosa sensitiva L. var. sensitiva, Sp. Pl.: 518. 1753. Figuras $2 \mathrm{j}, 6 \mathrm{~h}-\mathrm{m}$

Subarbustos prostrados a escandentes, 0,4-2 $\mathrm{m}$ alt. Tricomas tectores distribuídos nos ramos, estípulas, folíolos, pedúnculos, brácteas, corola e frutos. Ramos cilíndricos, aculeados, verdeamarelados, puberulentos; acúleos 1-3 mm compr., fortemente recurvados, dispostos em fileiras longitudinais, estendendo-se também sobre o eixo foliar e pedúnculo. Estípulas persistentes 3-4 $\times$ ca. $1 \mathrm{~mm}$, oval-lanceoladas, ciliadas. Folhas com 1 par de pinas; movimentos tigmonásticos rápidos; pecíolo 3,5-6 cm compr.; raque ausente.; segmentos da raque ausentes; espículas interpinais presentes; parafilídios subulados; folíolos 2 pares, 2,7-4,8 × 0,8-1,7 $\mathrm{cm}$, membranáceos, discolores, lanceolado-falcados, ápice cuneadomucronado, base truncada, margem ciliada, indumento adaxial glabro, indumento abaxial estrigoso-hirsuto, nervação broquidódroma. Glomérulos solitários, axilares, 2-2,7 cm diâm.; pedúnculo $2-3 \mathrm{~cm}$ compr.; brácteas 1,8-2 mm compr., linear-oblanceoladas, glabras, ápice ciliado. Flores tetrâmeras, isostêmones, sésseis, 65-103 por inflorescência; cálice ca. $1 \mathrm{~mm}$ compr., campanulado, com setas paleáceas, verde, glabro; corola 2-3 mm, campanulada, branca, externamente puberulenta; lacínias eretas ou incurvadas; filetes 8-9 mm compr., róseos; antera oblonga, verde-amarelada; ovário $0,5-1$ mm compr., esverdeado, séssil, glabro; estilete 8-9 mm compr., róseo. Craspédios 1,4-2,4(-3) × 0,5-0,7 cm, coriáceos, elíptico-oblongos, sésseis, plano-compressos, 3-4 articulados, ápice acuminadoarestado, base arredondada, hirsutos, marrom-amarelados; artículos retangulares, 4-5 × 5-6 mm; replo reto, hirsuto, armado com setas longas e rígidas. Sementes, 3-4 × 2-3 mm, ovoides, acinzentadas.

Material examinado: BRASIL, BAHIA: Jeremoabo, APA Serra Branca, Trilha que vai dos Quelés em direção a Estação Ecológica Raso da Catarina, 9S 56' 23", 38W 28' 6", $631 \mathrm{~m}, 23 / 9 / 2010$, D.A.O. Dourado 61, fr. (HUNEB); Entrada da APA, 9S 57' 30", 38W 26' 19", 650 m, 7/4/2011, D.A.O. Dourado 81, fl. (HUNEB); Trilha que vai dos Quelés em direção a Estação Ecológica Raso da Catarina, próximo a entrada da APA, 9S 57' 22', 38W 26' 56", 510 m, 7/4/2011, D.A.O. Dourado 91, fl. (HUNEB); 16/4/2011, D.A.O. Dourado 104, fl., fr. (HUNEB).

Segundo Barneby (1991), Mimosa sensitiva apresenta distribuição exclusiva da América do Sul. No Brasil ocorre na Bahia, Pernambuco, Minas Gerais e Amazônia (Barneby 1991, Santos-Silva \& Sales 2008, 2010). Para essa espécie foram reconhecidas duas variedades, com base no diâmetro da inflorescência, tamanho das brácteas e filetes: M. sensitiva var. malitiosa (Mart.) Barneby e M. sensitiva L. var. sensitiva, dentre essas apenas a variedade sensitiva é observada na APA, crescendo em áreas degradadas, antropizadas, ao longo das trilhas, em solo arenoso e arenoso-argiloso. É conhecida popularmente como unha-de-gato, malícia ou rasga beiço. Floresce de abril a setembro e frutifica de julho a outubro.

Caracteriza-se pelos acúleos fortemente recurvados, dispostos em fileiras longitudinais, estendendo-se também sobre o eixo foliar e pedúnculo, folíolos com movimentos tigmonásticos rápidos, pinas com quatro pares de folíolos lanceolado-falcados, sendo os mais internos atrofiados, nervação broquidódroma e frutos coriáceos, hirsutos.
11. Mimosa tenuiflora (Willd.) Poir., Encycl. (Lamarck), Suppl. 1: 82. 1811. Figuras $2 \mathrm{k}, 6 \mathrm{n}-\mathrm{t}$

Arbustos a arvoretas eretos, 2,5-5 $\mathrm{m}$ alt. Tricomas tectores e/ ou glandulares presentes nos ramos, estípulas, folíolos, pedúnculos, brácteas, cálice e frutos. Ramos cilíndricos, aculeados, castanhonigriscentes, pubescentes; acúleos 2-8 mm compr., retos. Estípulas decíduas 0,8-1 × ca. 0,5 mm, triangulares, ciliadas. Folhas com 4-7 pares de pinas; movimentos tigmonásticos ausentes; pecíolo $0,6-1,4$ cm compr.; raque 1-3,6 cm compr.; segmentos da raque 0,4-0,7 cm compr.; espículas interpinais presentes; parafilídios cônicos; folíolos 15-30 pares, 4-6 × 1-1,5 mm, cartáceos, concolores, oblongolineares, ápice arredondado, base oblíqua, margem discretamente ciliada, pontuações glandulares escuras translúcidas na face abaxial, glabros a puberulentos, nervação hifódroma. Espigas cilíndricas, solitárias, axilares 4,5-6 × 0,7-1 cm; pedúnculo 4-5 mm compr.; brácteas oboval-oblanceoladas, puberulentas, margens ciliadas. Flores tetrâmeras, diplostêmones, sésseis, 130-180 por inflorescência; cálice ca. $1 \mathrm{~mm}$ compr., campanulado, 4-angulado por nervura proeminente e recurvada, esverdeado, puberulento; corola 2-2,4 mm compr., campanulada, branca, puberulenta; lacínias incurvadas ou patentes; filetes 3-4 mm compr., brancos; antera oblonga, esverdeada; ovário ca. $1 \mathrm{~mm}$ compr., séssil, puberulento, estiletes 5-6 mm compr., brancos. Craspédios 2,5-3,4 × 0,7-0,8 cm, cartáceos, estipitados, plano-compressos, 4-8 articulados, oblongos, ápice cuneado-mucronado, base cuneada-atenuada, puberulentos, tricomas glandulares esparsos, inermes, marrom-amarelados; estípite 5-6 mm; artículos quadrangulares, 5-8 × 7-8 $\mathrm{mm}$; replo levemente ondulado, puberulento. Sementes 3-3,5 × 1-1,5 mm, ovóides, marrons.

Material examinado: BRASIL, BAHIA: Jeremoabo, APA Serra Branca, Trilha que vai dos Quelés em direção a Estação Ecológica Raso da Catarina, 9S 53' 1', 38W 32' 39”, 650 m, 22/9/2010, D.A.O. Dourado 58, fl. (HUNEB); 9S 52' 53", 38W 32' 42”, 650 m, 5/11/2010, D.A.O. Dourado 71, fl., fr. (HUNEB); 9S 53' 43", 38W 30' 34”, 650 m, 4/12/2010, D.A.O. Dourado 80, fr. (HUNEB); Fazenda Serra Branca, próximo à casa do IBAMA. Próximo a segunda porteira, 9S 55' 45”, 38W 42' 25”, 375 m, 10/9/2009, D.D. Vieira 16, fl. (HUNEB).

Mimosa tenuiflora é uma espécie amplamente distribuída no nordeste do Brasil, Venezuela, Colômbia e México, Honduras e El Salvador (Barneby 1991, Queiroz 2009, Santos-Silva \& Sales 2008, 2010). Na área de estudo, é uma espécie frequente, ocorrendo em áreas preservadas e degradadas, abertas e fechadas, em solo arenoso e areno-argiloso, com flores em setembro e frutos em dezembro. Conhecida popularmente, em grande parte da região semiárida, como jurema-preta. Das cascas e raízes dessa espécie, são elaboradas bebidas usadas em rituais, por grande número de comunidades indígenas do nordeste brasileiro. Está planta contém alta concentração de N-N-dimetiltriptamina (DMT), substância capaz de promover intensas alterações de consciência e percepção (Grünewald 2008).

Dentre as espécies estudadas, $M$. tenuiflora pode ser confundida com $M$. arenosa e $M$. acutistipula var. acutistipula, como mencionado anteriormente. No entanto, pode ser facilmente reconhecida por apresentar os ramos enegrescidos, folíolos com pontuações glandulares escuras na face abaxial, cálice tubuloso, 4-angulado devido à presença de nervuras proeminentes e encurvadas, filetes brancos e ovário puberulento. 


\section{Agradecimentos}

À FAPESB (Fundação de Amparo à Pesquisa do Estado da Bahia) pelo apoio financeiro ao projeto (PET 0023/2007) e concessão de bolsa de mestrado ao primeiro autor (BOL 0503/2010). Aos curadores e técnicos dos Herbários visitados, pela prontidão durante a consulta das coleções. Ao Natanael Santos pelas ilustrações botânicas.

\section{Referências Bibliográficas}

ALVES, J.J. 2007. Geoecologia da caatinga no semiárido do nordeste brasileiro. CLIMEP 2:58-71.

ANDRADE-LIMA, D. 1981. The Caatinga Dominium. Rev. Bras. Bot. 4:149-163.

BARNEBY, C.R. 1985. The genus Mimosa (Mimosoideae) in Bahia, Brazil: new taxa and nomenclatural adjustments. Brittonia 37:125-153. http:// dx.doi.org/10.2307/2806089

BARNEBY, C.R. 1991. Sensitivae Censitae. A description of the genus Mimosa L. (Mimosaceae) in the New World. Mem. New York Bot. Gard. 65:1-835.

BENTHAM, G. 1841. Notes on Mimoseae, with a short synopsis of species. J. Bot. 4:243-392.

BENTHAM, G. 1875. Revision of the suborder Mimoseae. Trans. Linn. Society London 30:335-664. http://dx.doi.org/10.1111/j.1096-3642.1875. tb00005.x

BENTHAM, G. 1876. Leguminosae-Mimosoideae. In Flora Brasiliensis (C.F.P. Martius, A.W. Eichler \& I. Urban, eds.). Munchen, Wein, Leipzig, v.2, p.456-458.

BESSEGA, C., HOPP, H.E. \& FORTUNATO, R.H. 2008. Toward a phylogeny of Mimosa (Leguminosae, Mimosoideae): a preliminary analysis of southern South American species based on chloroplast DNA sequence. Ann. Mo. Bot. Gard. 95:567-569. http://dx.doi.org/10.3417/2006012

BURKART, A. 1948. Las especies de Mimosa de la flora Argentina. Darwiniana 8:9-231.

CAMARGO-RICALDE, S.L. \& GRETHER, R. 1998. Germinación, dispersión y estabelecimento de plântulas de Mimosa tenuiflora (Leguminosae) en México. Rev. Biol. Trop. 46:543-554.

CAMARGO-RICALDE, S.L. \& GARCÍA-GARCÍA, V. 2001. El género Mimosa L. (Fabaceae) y la restauración ecológica. Contactos 39:34-42.

CASTELLETTI, C. H. M., SILVA, J.M.C., TABARELLI, M. \& SANTOS, A.M.M. 2004. Quanto ainda resta da Caatinga? Uma estimativa preliminar. In Biodiversidade da Caatinga: áreas e ações prioritárias para a conservação (J.M.C. Silva, M. Tabarelli, M. Fonseca \& L. Lins, eds.). Ministério do Meio Ambiente, Brasília, p.91-100.

COUTINHO, A.P.S. 2009. Taxonomic Revision and Phylogenetic Studies of Mimosa L. sect. Calothamnos Barneby (Leguminosae-Mimosoideae). Tese de Doutorado, Universidade de São Paulo, São Paulo.

DUCKE, A. 1953. As leguminosas de Pernambuco e Paraíba. Mem. I. Oswaldo Cruz 51:417-461. http://dx.doi.org/10.1590/S0074-02761953000100011

DUTRA, V.F. \& MORIM, M.P. 2010. Mimosa. In Lista de Espécies da Flora do Brasil (R.C. Forzza, P.M. Leitman, A.F. Costa, A.A. Carvalho Junior, A.L. Peixoto, B.M.T. Walter, C. Bicudo, D. Zappi, D.P. Costa, E. Lleras, G. Martinelli, H.C. Lima, J. Prado, J.R. Stehmann, J.F.A. Baumgratz, J.R. Pirani, L. Sylvestre, L.C. Maia, L.G. Lohmann, L.P. Queiroz, M. Silveira, M.N. Coelho, M.C. Mamede, M.N.C. Bastos, M.P. Morim, M.R. Barbosa, M. Menezes, M. Hopkins, R. Secco, T.B. Cavalcanti \& V.C. SOUZA, orgs.). Jardim Botânico do Rio de Janeiro. http://floradobrasil.jbrj.gov. br/2010/FB023084 (último acesso em 03/11/2011).

FERNANDES, A.G. \& BEZERRA, P. 1990. Estudo Fitogeográfico do Brasil. Stylus Comunicações, Fortaleza.

FOSBERG, F.R. \& SACHET, M.H. 1965. Manual for tropical herbaria. Utrecht, Netherlands.

GIL, P.R. 2002. Wilderness - Earth's cast wild places. CEMEX, México.

GIULIETTI, A.M., R.M. HARLEY, L.P. QUEIROZ, M.R.V. BARBOSA, A.L.B. NETA, E M.A. FIGUEIREDO. 2002. Espécies endêmicas da caatinga. In Vegetação e flora da caatinga (E.V.S.B. Sampaio, A.M. Giulietti, J. Virgínio \& C.F.L. Gamarra-Rojas, eds.). APNE, Recife, p.11-24.

GIULIETTI, A.M.; BOCAGE NETA, A.L.; CASTRO, A.A.J.F.; GAMARRAROJAS, C.F.L.; SAMPAIO, E.V.S.B.; VIRGÍNIO, J.F.; QUEIROZ, L.P.; FIGUEIREDO, M.A.; RODAL, M.J.N.; BARBOSA, M.R.V. \& HARLEY, R.M. 2004. Diagnóstico da vegetação nativa do bioma caatinga. In Biodiversidade da Caatinga: áreas e ações prioritárias para a conservação (J.M.C. Silva, M. Tabarelli, M.T. Fonseca \& M.V. Lins, eds.). MMA, Brasília, p.47-90.

GRÜNEWALD, R.A. 2008. Toré e Jurema: Emblemas Indígenas do Brasil. Ciênc. Cultura 60:43-45.

HARLEY, R.M. \& SIMMONS, N.A. 1986. Florula of Mucugê-Chapada da Diamantina, Bahia, Brazil. Royal Botanic Gardens, Kew.

HARRIS, J.G. \& HARRIS, M.W. 1994. Plant identification terminology: an illustrated glossary. 2nd ed. Spring Lake Publishing, Spring Lake.

INSTITUTO BRASILEIRO DO MEIO AMBIENTE E DOS RECURSOS NATURAIS RENOVÁVEIS - IBAMA. Estação Ecológica Raso da Catarina. 2004. Disponível em: <http://www.ibama.gov.br/siucweb/ mostraUc.php?seqUc=148>. (último acesso em 23/02/2013).

JOBSON, R.W. \& LUCKOW, M. 2007. Phylogenetic study of the genus Piptadenia (Mimosoideae: Leguminosae) using plastid trnL-F and trnK/matK sequence data. Syst. Bot. 32:569-575. http://dx.doi. org/10.1600/036364407782250544

LEAL, I.R., TABARELLI, M. \& SILVA, J.M.C. 2003. Ecologia e conservação da Caatinga. Editora Universitária, Universidade Federal de Pernambuco, Recife, Brasil.

LEAL, I.R., SILVA, J.M.C., TABARELLI, M. \& LACHER JR., T.E. 2005. Mudando o curso da conservação da biodiversidade na Caatinga do Nordeste do Brasil. Megadiversidade. 1(1):139-146.

LEWIS, G.P. 1987. Legumes of Bahia. Royal Botanic Gardens, Kew.

LEWIS, G.P. 1995. Leguminosae. In Flora of the Pico das Almas Chapada Diamantina, Bahia, Brazil (B.L. Stannard, ed). Royal Botanic Gardens, Kew, p.368-394.

LEWIS, G.P., SCHRIRE, B., MacKINDER, B. \& LOCK, M. 2005. Legumes of the world. Royal Botanic Gardens, Kew.

LEWIS, G.P. 2006. Leguminosae subfamília Mimosoideae. In Checklist das plantas do Nordeste brasileiro: angiospermas e gymnospermas (M.R.V. Barbosa, C. Sothers, S. Mayo, C.F.L. Gamarra-Rojas \& A.C. Mesquita, orgs.). Ministério da Ciência e Tecnologia, Brasília, p.86-90.

LINNAEUS, C. 1753. Mimosa. In Species plantarum (C. Linnaeus, org). Imprensis Laurentii Salvii, Paris, p.516-523.

LUCKOW, M., WHITE, P.J. \& A. BRUNEAU. 2000. Relationships among the basal genera of mimosoid legumes. In Advances in Legumes Systematics (P.S. Herendeen \& A. Bruneau, eds.). Royal Botanic Gardens, Kew, p.165-180.

LUCKOW, M., MILLER J.T., MURPHY, D.J. \& LIVSHULTZ, T. 2003. A phylogenetic analysis of the Mimosoideae (Leguminosae) based on chloroplast DNA sequence data. In Advances in Legume Systematics (B.B. Klitgaard \& A. Bruneau, eds.). Royal Botanic Gardens, Kew, p.197-220.

MORI, S.A., SILVA, A.M., LISBOA, A. \& CORADIN, L. 1989. Manual de manejo de herbário fanerogâmico. 2. ed. Centro de pesquisas do Cacau, Ilhéus.

QUEIROZ, L.P. 2002. Distribuição das espécies de Leguminosae na caatinga. In Vegetação \& flora da caatinga (E.V.S.B. Sampaio, A.M. Giulietti, J. Virgínio \& C.F.L. Gamarra-Rojas, eds.). Recife, Associação de Plantas do Nordeste - APNE, p.141-153.

QUEIROZ, L.P. 2009. Leguminosas da Caatinga. Editora Universitária da UEFS, Feira de Santana.

RADFORD, A.E., DICKINSON, W.C., MASSEY, J.R. \& BELL, C.R. 1974. Vascular plant systematics. Harper et Row, New York.

SAMPAIO, E.V.S.B. 1995. Overview of the Brazilian Caatinga. In Seasonally dry tropical forests (S. Bullock, H. Mooney \& E. Medina, 
eds.). Cambrige University Press, p.34-63. http://dx.doi.org/10.1017/ CBO9780511753398.003

SANTOS-SILVA, J. \& SALES, M.F. 2008. O gênero Mimosa (LeguminosaeMimosoideae) na microrregião do Vale do Ipanema, Pernambuco. Rodriguésia 59:435-448.

SANTOS-SILVA, J. \& SALES, M.F. 2010. Diversidade e potencial econômico de Mimosa L. (Leguminosae-Mimosoideae) em Pernambuco, Brasil. In Biodiversidade, potencial econômico e processos ecofisiológicos em ecossistemas nordestinos (U.P. Albuquerque, A.N. Moura \& E.L. Araújo, eds). NUPEEA, Recife, p.283-313.

SIMON, M.F., GRETHER, R., QUEIROZ, L.P., SARKINEN, T.E., DUTRA V.F. \& HUGHES, C.E. 2011. The evolutionary history of Mimosa
(Leguminosae): Toward a phylogeny of the sensitive plants. Am. J. Bot. 98:1201-1221. http://dx.doi.org/10.3732/ajb.1000520

SULAIMAN, S.F., CULHAM, A. \& HARBORNE, J.B. 2003. Molecular phylogeny of Fabaceae based on rbcL sequence data: with special emphasis on the tribe Mimoseae (Mimosoideae). Asia-Pac. J. Mol. Biol. 11:9-35.

THIERS, B. 2011. Index Herbariorum: A global directory of public herbaria and associated staff. New York Botanical Garden's Virtual Herbarium. http://sweetgum.nybg.org/ih/ (último acesso em 23/02/2013).

VELLOSO, A.L., SAMPAIO, E.V.S.B. \& PAREYN, F.G.C. 2002. Ecorregiões propostas para o Bioma Caatinga. Associação Plantas do Nordeste, Recife.

Recebido em 22/06/2013

Versão reformulada recebida em 01/10/2013

Publicado em 06/11/2013 


\section{Apêndice}

Apêndice 1. Lista de material adicional examinado.

Appendix 1. List of additional material examined.

Almeida, E.F. 1 (3); Barreto, M. 50 (11); Bastos, B.B. 539 (3); Bautista, H.P. 263 (11), 741 (5), 1508 (1), 1596 (4); Brazão, J.E.M. 226 (2); Cardoso, D. 79 (1), 90 (11), 128 (3); Carneiro, D. 1810 (11); Carneiro, J. 75550 (3); Carvalho, A. 3151 (3); Carvalho, G.M. 23 (4); Carvalho-Sobrinho, J.G. 398 (1); Conceição, A.A. 2807 (2); Cordeiro, L.M. 96 (11), 142 (11), 173 (11); Edna, L.P.G. 776 (8); Fotius, G. 3477 (1); Giulietti, A.M. 1803 (1), 1862 (1), 2024 (2), 2059 (3); Gonçalves, L.M.C. 90 (10); Guedes, M.L. 7315 (1), 10527 (11), 13120 (11), 13900 (5), 14114 (5), 15826 (1), 16907 (5), 17031 (10), 18224 (8), 18319 (10); Guimarães, M.D.M. 32 (11); Hage, J.L. 1854 (4); Harley, R.M. 7491 (11), 7492 (10), 19112 (6), 54862 (6); Hatschbach, G. 39516 (11), 42092 (1), 42305 (11), 44275 (11), 50041 (11), 53356 (11), 63085 (5), 63226 (10), 63351 (8), 65104 (10), 67747 (1), 68432 (8), 75394 (8), 78484 (9), 78675 (11); Jesus, N.G. 140 (8); Lewis, G.P. 936 (10); Lima, L.C.L. 174 (3), 175 (2); Loureiro, D.M. 309 (11); Machado, T.O. 5 (5); Martins, M. 1628 (3); Melo, E. 6632 (5), 6698 (3), 6789 (6), 7332 (6); Miranda, E.B. 619 (5); Moruz, C.V.A. 68 (8); Nascimento, A.F.S. 52 (3); Nascimento, N.S. 3704 (5), 3734 (5), 4550 (2); Noblick, L.R. 1610 (10), 2629 (4), 2849 (5), 3418 (5); Nunes, T.C. 376 (9), 398 (11), 479 (11), 500 (11); Pacheco, L.M. 32 (8); Passos, L.P. 257 (3); Pereira, G. 9093 (2); Pereira, R. 1129 (3); Oliveira, A. 13 (10); Oliveira, C.G. 336 (1); Oliveira, E. 137 (5); Oliveira, E.L.P.G. 170 (10), 677 (11), 795 (10); Oliveira, L.B. 7 (2); Orlandi, R.P. 329 (5), 442 (10); Queiroz, L.P. de 96 (3), 436 (11), 1702 (11), 2612 (10), 2677 (9), 3830 (3), 3846 (9), 4427 (8), 4432 (9), 4546 (5), 4663 (3), 4870 (1), 6561 (1), 6580 (1), 7322 (3), 7924 (3), 9576 (3); 10064 (1); Ribas, O.S. 75661 (3); Roque, N. 1782 (4); Salgado, O.A. 378 (3); Santos, J.B. 2347 (5); Sena, T.S.N. 3247 (3); Silva, L.A.M. 2046 (10); Silva, R.A. 1127 (11), 1460 (4), 1659 (11), 1853 (1); Silva, S.B. 367 (1); Silva, T.R.S. 96 (2); Souza, V.C. 2122 (4); Tourinho, R. 37 (1); Wilson, G. 3260 (2). 